\title{
1. Elucidating Dramatic Ligand Effects on SET Processes: Iron Hydride 2 versus Iron Borohydride Catalyzed Reductive Radical Cyclization of ${ }_{3}$ Unsaturated Organic Halides
}

${ }_{4}$ Sara H. Kyne, ${ }^{\dagger, \perp \odot ~ M a r t i n ~ C l e ́ m a n c e y, ~}{ }^{\ddagger}$ Geneviève Blondin, ${ }^{\ddagger}$ Etienne Derat, ${ }^{\dagger} \odot$ Louis Fensterbank, ${ }^{*}, \dagger$ s Anny Jutand, ${ }^{*}$, Guillaume Lefevre, ${ }^{*}, \| \odot$ and Cyril Ollivier ${ }^{* \dagger}$

$6{ }^{\dagger}$ Sorbonne Universités, UPMC Univ Paris 06, CNRS, UMR 8232, Institut Parisien de Chimie Moléculaire, 4 place Jussieu, F-75252

7 Paris Cedex 05, France

8 Université Grenoble Alpes, CEA, CNRS, LCBM (UMR 5249), pmb, F-38000 Grenoble, France

$9{ }^{\S}$ Ecole Normale Supérieure-PSL Research University, Département de Chimie, Sorbonne Universités, UPMC Univ Paris 06, CNRS

10 UMR 8640 PASTEUR, 24 Rue Lhomond, F-75231 Paris Cedex 05, France

11 "NIMBE, CEA, CNRS, Université Paris-Saclay, Gif-sur-Yvette, France

12 S Supporting Information

13 ABSTRACT: An iron(II) borohydride complex $\left(\left[\left(\eta^{1}-\mathrm{H}_{3} \mathrm{BH}\right)-\right.\right.$

$\left.\left.14 \mathrm{FeCl}\left(\mathrm{NCCH}_{3}\right)_{4}\right]\right)$ is employed as the precatalyst in iron-catalyzed

15 radical cyclizations of unsaturated organic halides in the presence of

$16 \mathrm{NaBH}_{4}$. Mechanistic investigations have established that the ligand

17 bound to the metal center (acetonitrile versus ethylenebis-

18 (diphenylphosphine) (dppe)) plays a crucial role in the structure

19 and reactivity of the active anionic iron(I) hydride ([HFeCl-

20 (dppe $\left.\left.)_{2}\right]^{-}\right)$and borohydride $\left(\left[\left(\eta^{1}-\mathrm{H}_{3} \mathrm{BH}\right) \mathrm{FeCl}\left(\mathrm{NCCH}_{3}\right)_{4}\right]^{-}\right)$with

21 unsaturated haloacetals. This work provides new insights into

22

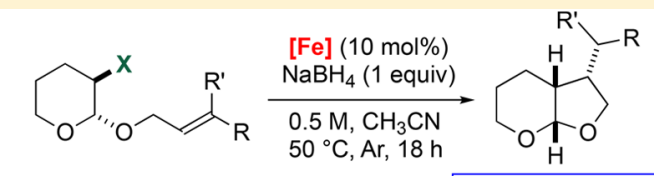

$X=1$ only $[\mathrm{Fe}]=\left[\mathrm{HFeCl}(\text { dppe })_{2}\right]$ $X=1$ or $\mathrm{Br}[\mathrm{Fe}]=\left[\mathrm{H}_{3} \mathrm{BH}-\mathrm{FeCl}\left(\mathrm{NCCH}_{3}\right)_{4}\right]$ Mechanistic studies: Electrochemistry, Mössbauer, spectroscopy, computational analysis iron(I) hydride and borohydride species and their potential implication in single-electron processes.

\section{INTRODUCTION}

24 Transition metals have been widely employed in radical 25 chemistry $^{1}$ since the pioneering works of Kochi and co26 workers, which documented the importance of single-electron27 transfer (SET) processes in such metal-catalyzed reactions. ${ }^{2}$ 28 Particularly, transition-metal complexes with low oxidation state 29 readily undergo reduction of organic substrates to form a 30 variety of carbon-centered radicals under the appropriate 31 reaction conditions. ${ }^{3}$ Among these, it has been proposed that 32 metal hydride complexes, which have proven their efficiency in 33 catalysis and organic synthesis, ${ }^{4}$ generate low-valent transition34 metal hydride species under reducing conditions, acting as both 35 mediators and hydrogen donors for reductive radical reactions 36 with organic halides. However, the in situ formation of the 37 transition-metal hydride species, generated from the corre38 sponding metal-halogenated complexes and a stoichiometric 39 amount of hydride source $\left(\mathrm{LiAlH}_{4}, \mathrm{NaBH}_{4}, \mathrm{NaBH}_{3} \mathrm{CN}\right.$, Red$40 \mathrm{Al}$ ), and the subsequent reaction mechanism have both 41 remained largely unexplored. Such radical transformations 42 have been performed with metal complexes of gallium, ${ }^{5}$ 43 indium, ${ }^{6}$ zirconium, ${ }^{7}$ or titanium. ${ }^{8}$ While plausible mechanisms 44 for these reactions have been proposed, tangible evidence is still 45 anecdotal. For instance, Oshima and co-workers used 46 commercially available Schwartz reagent (bis47 (cyclopentadienyl)zirconium(IV) chloride hydride) as a 48 stoichiometric reducing reagent, or catalytic reaction conditions of $20 \mathrm{~mol} \%$ [ $\left.\mathrm{Cp}_{2} \mathrm{ZrCl}_{2}\right]$ in the presence of Red-Al, and $\mathrm{Et}_{3} \mathrm{~B}$ to 49 promote reductive radical cyclization reactions of haloacetals. 50 The authors proposed that the zirconium hydride $(\mathrm{Zr}-\mathrm{H})_{51}$ species was formed in situ from $\left[\mathrm{Cp}_{2} \mathrm{ZrCl}_{2}\right]$ in the presence of 52 the strong reducing agent and acted as the precatalyst for the 53 reaction. Hydrogen atom abstraction would give rise to the 54 active zirconium(III) radical which undergoes SET with the 55 substrate. $^{7}$ In one of the earliest examples of this chemistry, 56 Schwartz employed substoichiometric $\left[\mathrm{Cp}_{2} \mathrm{TiCl}_{2}\right]$ in the 57 presence of a large excess of sodium borohydride for an aryl 58 halide reductive cyclization reaction (Scheme 1). Mechanistic $59 \mathrm{~s} 1$ studies were carried out on the titanium borohydride complex 60 $\left[\mathrm{Cp}_{2} \mathrm{Ti}\left(\mathrm{BH}_{4}\right)\right]$ which was presumably formed under the 61 reaction conditions. A titanium hydride amine complex 62 $\left(\mathrm{Cp}_{2} \mathrm{Ti}^{\mathrm{III}} \mathrm{H} \cdot\right.$ amine $)$ was suggested to be responsible for electron 63 transfer. Evidence of this species was circumstantial but showed 64 that the rate of cleavage of the $\mathrm{Ti}-\mathrm{HBH}_{3}$ bond varied in the 65 presence of different amines such as pyridine and $\mathrm{N}, \mathrm{N}-66$ dimethylethylamine. ${ }^{8}$ These studies led to the conclusion that 67 metal hydride and borohydride complexes can both act as 68 precatalysts of the reduction reaction of organic halides 69

Special Issue: Organometallic Chemistry in Europe

Received: August 5, 2017 
Scheme 1. Transition-Metal-Mediated Radical Reactions and Postulated Intermediates Formed in Situ
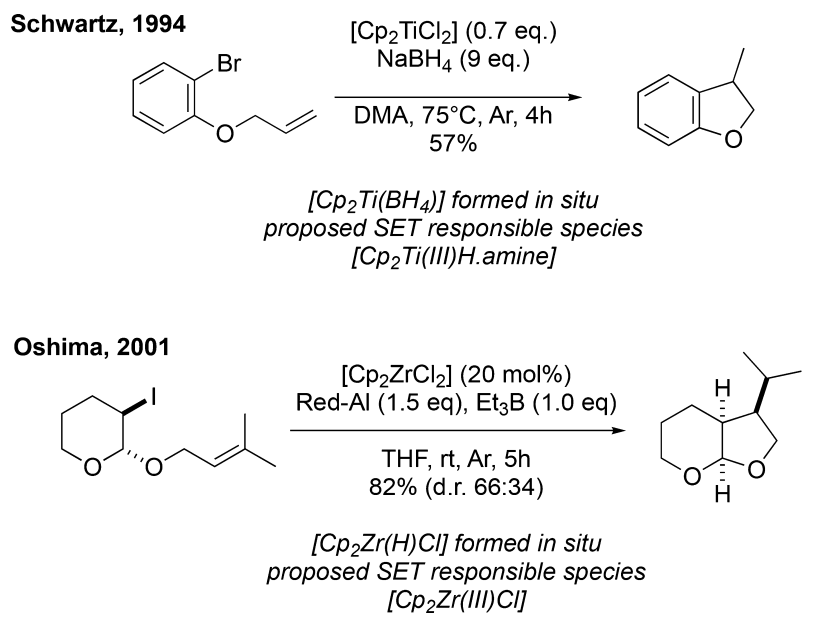

70 depending on the nature of the metal and potentially also the 71 ligand.

72 Iron is reactive in redox chemistry: in particular, an array of 73 reduction reactions has been carried out in the presence of 74 metal reducing agents. Thanks principally to the pioneering 75 work by Kharash and Kochi, iron catalysts have been exploited 76 in a broad range of cross-coupling reactions of alkyl halides with 77 Grignard reagents. ${ }^{9}$ Meunier and co-workers first reported that 78 a stoichiometric amount of an iron-magnesium complex 79 ( $\mathrm{Cp}$ (DIPHOS)FeMgBr) mediated the 5-exo radical cyclization 80 reaction of 5-hexenyl bromide. ${ }^{10}$ Oshima and co-workers 81 developed intramolecular radical cyclization reactions of 82 haloacetals in the presence of $5 \mathrm{~mol} \%$ of iron(II) dichloride 83 and a stoichiometric Grignard reagent as the reducing agent. ${ }^{11}$

84 Other iron-mediated reduction reactions have also been 85 developed, ${ }^{12}$ and particularly, other mixed iron(II) or iron86 (III)/hydride systems have also been applied to several 87 different radical transformations. ${ }^{13}$

88 Over the last 50 years, various iron monohydride ${ }^{14}$ and 89 borohydride ${ }^{15}$ complexes have been reported in the literature, 90 but their use in radical synthesis remains scarce.

91 In an initial communication, we reported a novel 5-exo 92 cyclization of 2-allyloxy-3-halotetrahydropyrans $\left(\mathbf{1}_{\mathrm{I}}, \mathbf{1}_{\mathrm{Br}}\right)$ in the 93 presence of iron(II) dichloride and sodium borohydride 94 (Scheme 2). ${ }^{16}$

Scheme 2. Reaction of Haloacetals (1) in the Presence of Iron(II) Complexes and $\mathrm{NaBH}_{4}$

$$
\begin{aligned}
& 1_{\mathrm{I}} \mathrm{X}=1 \\
& 1_{\mathrm{Br}} \mathrm{X}=\mathrm{Br}
\end{aligned}
$$

Table 1. Reactivity of 1 in the Presence of $[\mathrm{Fe}](10 \mathrm{~mol} \%)$ and $\mathrm{NaBH}_{4}{ }^{a}$

\begin{tabular}{cclcc} 
entry & substrate & \multicolumn{1}{c}{$[\mathrm{Fe}]$} & $\mathrm{NaBH}_{4}$ (equiv) & yield (\%) \\
1 & $\mathbf{1}_{\mathbf{I}}$ & $\mathrm{FeCl}_{2}$ & 1.50 & $73^{b}$ \\
2 & $\mathbf{1}_{\mathrm{Br}}$ & $\mathrm{FeCl}_{2}$ & 1.50 & $78^{b}$ \\
3 & $\mathbf{1}_{\mathbf{I}}$ & {$\left[\mathrm{HFeCl}(\mathrm{dppe})_{2}\right]$} & 1.00 & $70^{c}$ \\
4 & $\mathbf{1}_{\mathrm{Br}}$ & {$\left[\mathrm{HFeCl}(\mathrm{dppe})_{2}\right]$} & 1.00 & 0
\end{tabular}

${ }^{a}$ Reaction conditions: 1 (1.0 mmol, $0.5 \mathrm{M}$ in $\left.\mathrm{CH}_{3} \mathrm{CN}\right),[\mathrm{Fe}](10 \mathrm{~mol}$ \%), $\mathrm{NaBH}_{4}$ (X equiv), $50{ }^{\circ} \mathrm{C}, 18$ h. ${ }^{b} \mathrm{dr}=87: 13 .{ }^{c} \mathrm{dr}=90: 10$.

$3)$. Interestingly, no reaction was observed with the dihydride 103 counterpart, $\left[\mathrm{H}_{2} \mathrm{Fe}(\text { dppe })_{2}\right]$.

Electrochemical studies of $\left[\mathrm{HFe}^{\mathrm{II}} \mathrm{Cl}(\mathrm{dppe})_{2}\right]$ (3) identified 105 that an anionic iron(I) hydride species, $\left[\mathrm{HFe}^{\mathrm{I}} \mathrm{Cl}(\mathrm{dppe})_{2}\right]^{-} 106$ $\left(3^{-}\right)$, was electrogenerated or formed in the presence of 107 $\mathrm{NaBH}_{4}$. This species $\left(3^{-}\right)$was the active catalyst for the 108 reaction, activating iodoacetal $\left(\mathbf{1}_{\mathrm{I}}\right)$ by electron transfer (SET) 109 and regenerating the precatalyst in a catalytic cycle (Scheme 3 ). $110 \mathrm{~s} 3$

Scheme 3. Electrochemical Generation of $\left[\mathrm{HFe}^{\mathrm{I}} \mathrm{Cl}(\mathrm{dppe})_{2}\right]^{-}$ $\left(3^{-}\right)$and Electron Transfer (SET) to $1_{I}$

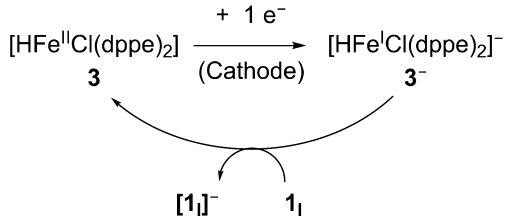

As shown in Scheme 4, during followup investigations we 111 s4 discovered that bromoacetal $\left(\mathbf{1}_{\mathrm{Br}}\right)$, in contrast to iodoacetal 112

Scheme 4. No Reaction of Bromoacetal $\left(1_{\mathrm{Br}}\right)$ in the Presence of $\left[\mathrm{HFeCl}(\text { dppe })_{2}\right]$ (3) and $\mathrm{NaBH}_{4}$

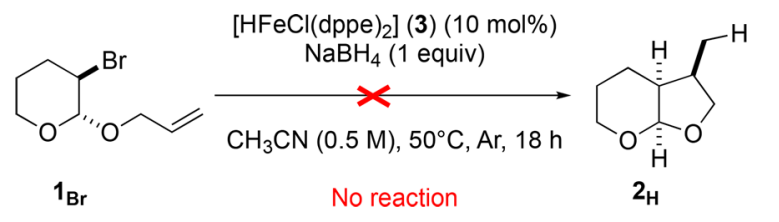

$\left(\mathbf{1}_{\mathrm{I}}\right)$, was completely unreactive in the presence of [HFeCl- 113 (dppe $)_{2}$ ] (3) (Table 1 , entry 4$){ }^{16 \mathrm{~b}}$

Herein, we report in detail the explanation for the lack of 115 reactivity of $\left[\mathrm{HFe}^{\mathrm{I}} \mathrm{Cl}(\mathrm{dppe})_{2}\right]^{-}$with bromoacetal $\left(\mathbf{1}_{\mathrm{Br}}\right)$ and our 116 investigation to better understand the important factors that 117 determine the reactivity of iron hydride complexes. We have 118 elucidated the crucial role played by the ligand, thus giving new 119 insights into the reactivity of iron hydride complexes to mediate 120 radical cyclization reactions. To our knowledge, no detailed 121 mechanistic investigations have been reported on iron- 122 mediated radical reactions involving the in situ formation of 123 an iron hydride versus borohydride species in acetonitrile. In 124 this article we discuss our efforts to expand the understanding 125 of iron-mediated reductive radical reactions.

RESULTS AND DISCUSSION 127

Synthesis and Characterization of Iron(II) Bis-Chloride 128 Complexes in Acetonitrile. As previously mentioned, an 129 iron(II) hydride complex $\left(\left[\mathrm{HFeCl}(\mathrm{dppe})_{2}\right](3)\right)$ serves as a 130 precatalyst for reductive 5-exo radical cyclization reactions. This 131 structurally defined complex can be easily synthesized from 132 
133 iron(II) dichloride upon reaction with sodium borohydride and 134 dppe. $^{17}$ This led us to consider the identity of the precatalyst 135 formed in situ from the same source of iron(II) in the presence 136 of sodium borohydride in acetonitrile in the absence of any 137 phosphine ligand. Acetonitrile is usually considered as a pure $\sigma$ 138 donor ligand and will readily fill vacant metal coordination sites 139 to provide stability in solution. ${ }^{18}$ Indeed, literature reports 140 supported the formation of iron-acetonitrile species. These 141 complexes have even been isolated and characterized; however, 142 their chemistry has not been greatly explored. ${ }^{19}$

143 Miller and co-workers have reported the solvation of iron(II) 144 dichloride with acetonitrile to give an isolated species. ${ }^{20}$ The 145 crystal structure revealed the $1 \mathrm{D}$ chain polymer dichlorobis146 (acetonitrile)iron(II) $\left(\left\{\mathrm{Fe}(\mu-\mathrm{Cl})_{2}\left(\mathrm{NCCH}_{3}\right)_{2}\right\}_{n} \quad(4)\right)$. This 147 species was first described in 1964 by Hathaway and Holah 148 and characterized by IR spectroscopy and titration. ${ }^{19 a} \mathrm{~A}$ 149 procedure to synthesize the dichlorotetrakis(acetonitrile)iron150 (II) complex $\mathrm{FeCl}_{2}\left(\mathrm{NCCH}_{3}\right)_{4}$ is also available. ${ }^{21}$

151 The dichlorobis(acetonitrile)iron(II) complex ( $\{\mathrm{Fe}(\mu$ $\left.\left.152 \mathrm{Cl})_{2}\left(\mathrm{NCCH}_{3}\right)_{2}\right\}_{n}(4)\right)$ was synthesized following the procedure 153 reported by Miller and co-workers, giving off-white crystals in $15485 \%$ yield (Scheme 5). ${ }^{20}$ The X-ray structure matched the

Scheme 5. Synthesis of $\left\{\mathrm{Fe}(\mu-\mathrm{Cl})_{2}\left(\mathrm{NCCH}_{3}\right)_{2}\right\}_{n}$ (4)

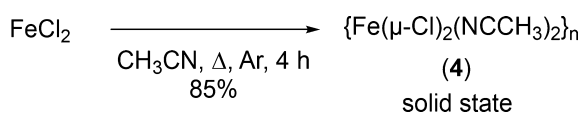

155 literature data. In this chain, an octahedral environment is 156 accommodated by the iron centers, with bridging chloride 157 anions and acetonitrile molecules in an apical position.

158 High-resolution ESI mass spectrometry revealed the 159 presence of $\left[\mathrm{FeCl}\left(\mathrm{NCCH}_{3}\right)_{2}\right]^{+}$, a fragment resulting from the 160 loss of one chloride ligand in the unit motif of the monomer 161 (calcd 172.95634, found 172.95654).

162 The Mössbauer spectrum recorded at $80 \mathrm{~K}$ on a powder 163 sample of $\left\{\mathrm{Fe}(\mu-\mathrm{Cl})_{2}\left(\mathrm{NCCH}_{3}\right)_{2}\right\}_{n}$ (4) (natural abundance in $\left.164{ }^{57} \mathrm{Fe}\right)$ reveals three doublets. The major doublet $(64 \%)$ has 165 nuclear parameters that are characteristic of high-spin $(S=2)$ $166 \mathrm{Fe}^{\mathrm{II}}\left(\delta=1.24 \mathrm{~mm} \mathrm{~s}^{-1}, \Delta E_{\mathrm{Q}}=2.07 \mathrm{~mm} \mathrm{~s}^{-1}\right)$. The isomer shift 167 value is in agreement with that previously determined for an 168 analogous 1D chain. ${ }^{22}$ The second doublet $\left(\delta=1.20 \mathrm{~mm} \mathrm{~s}^{-1}\right.$, $169 \Delta E_{\mathrm{Q}}=1.34 \mathrm{~mm} \mathrm{~s}^{-1}$, contribution $\left.26 \%\right)$ also exhibits nuclear 170 parameters featuring a high-spin $\mathrm{Fe}^{\mathrm{II}}$ ion. The two species differ 171 in the quadrupole splitting values, suggesting that the two 172 molecules of acetonitrile may be in either the trans or cis 173 positions. The third doublet $\left(\delta=0.34 \mathrm{~mm} \mathrm{~s}^{-1}, \Delta E_{\mathrm{Q}}=1.12 \mathrm{~mm}\right.$ $174 \mathrm{~s}^{-1}$, contribution $\left.10 \%\right)$ presents nuclear parameters that are 175 close to those of the tetrahedral ferric ion in $\left[\mathrm{N}_{6} \mathrm{Fe}^{\mathrm{III}}-(\mu-\mathrm{O})-\right.$ $\left.176 \mathrm{Fe}^{\mathrm{III}} \mathrm{Cl}_{3}\right]^{+}, 23$ suggesting a slight contamination by the diferric $\mu$ 177 oxo species $\left[\mathrm{Cl}_{3} \mathrm{Fe}-(\mu-\mathrm{O})-\mathrm{FeCl}_{3}\right]^{2-}$.

178 In order to investigate more closely the nature of the 179 transient iron species generated in situ in the catalytic 180 cyclization described in this work (Scheme 2), Mössbauer 181 spectra of frozen solutions containing ${ }^{57} \mathrm{Fe}$-enriched samples 182 were recorded. First, $\left\{{ }^{57} \mathrm{Fe}(\mu-\mathrm{Cl})_{2}(S)_{2}\right\}_{n}\left(S=\mathrm{NCCH}_{3}\right)$ was 183 synthesized following Miller's procedure, at $0.05 \mathrm{M}$ concen184 tration to mimic the cyclization conditions (Scheme 5). An 185 aliquot of this solution was frozen without preliminary 186 purification, and the Mössbauer spectrum was recorded at 80 $187 \mathrm{~K}$. Most of the spectrum (ca. $90 \%$ of the total area) could be 188 simulated with two quadrupole doublets (I and II, Figure 1a)

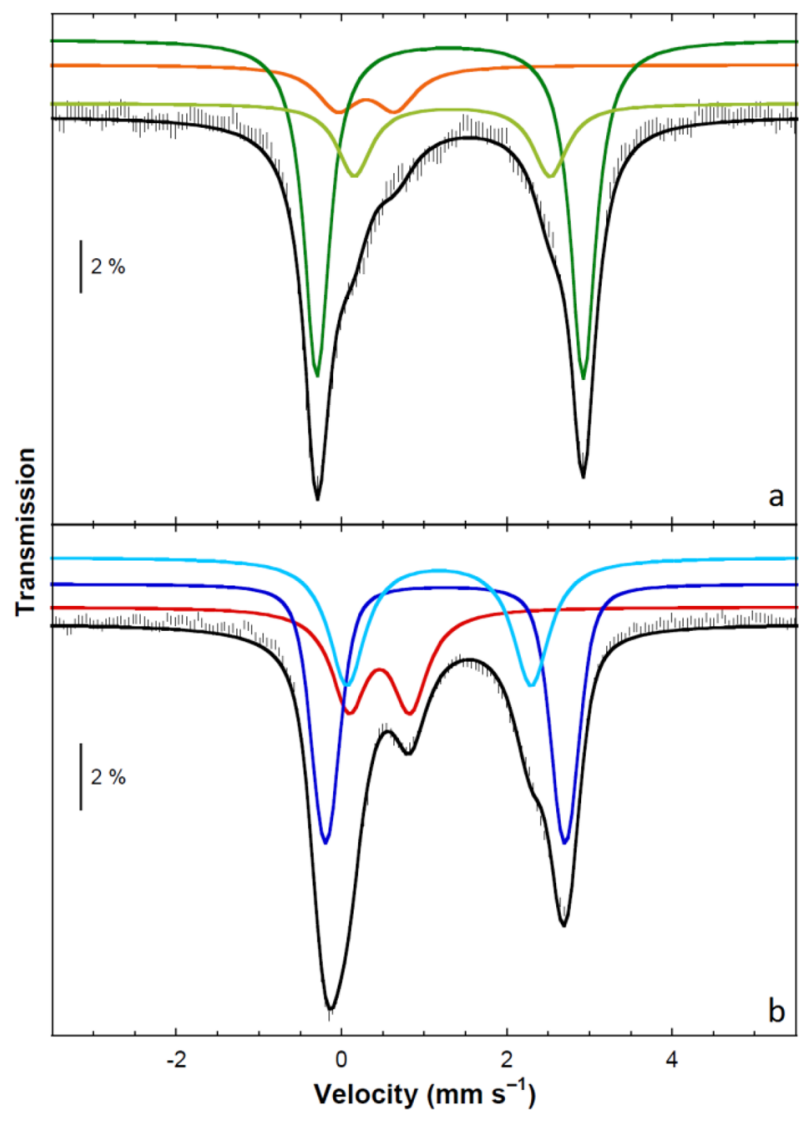

Figure 1. Zero-field Mössbauer spectra recorded at $80 \mathrm{~K}$ on acetonitrile solutions of ${ }^{57} \mathrm{FeCl}_{2}$ before (a) and after (b) the addition of 53 equiv of $\mathrm{NaBH}_{4}$. Experimental data are shown as hatched bars, and simulations are overlaid as solid black lines. Contributions are shown in color as upper traces. See text and Table 2 for parameters.

characteristic of two high-spin $\mathrm{Fe}^{\mathrm{II}}$ species $(S=2)$ featuring the 189 metal in an octahedral environment $\left(\delta_{\mathrm{I}}=1.31 \mathrm{~mm} \mathrm{~s}^{-1}, \Delta E_{\mathrm{Q}, \mathrm{I}}=190\right.$ $3.22 \mathrm{~mm} \mathrm{~s}^{-1}(67 \%)$ and $\delta_{\mathrm{II}}=1.34 \mathrm{~mm} \mathrm{~s}^{-1}, \Delta E_{\mathrm{Q}_{\text {II }}}=2.37 \mathrm{~mm} 191$ $\left.\mathrm{s}^{-1}(19 \%)\right)$, in agreement with literature data. ${ }^{24}$ Therefore, 192 these results suggest that at the reaction concentration $(0.05193$ M) the iron ion adopts an octahedral environment in 194 acetonitrile. In addition, the isomer shift is $0.1 \mathrm{~mm} \mathrm{~s}^{-1}$ higher 195 than that in the solid state. The same increase has been 196 previously measured at room temperature on powder samples 197 between $\mathrm{FeCl}_{2} \cdot 2 \mathrm{H}_{2} \mathrm{O}$ presenting the same polymeric $1 \mathrm{D}$ chain 198 $\left(\delta=1.12 \mathrm{~mm} \mathrm{~s}^{-1}\right)$ and $\mathrm{FeCl}_{2} \cdot 4 \mathrm{H}_{2} \mathrm{O}$, where the ferrous ions are 199 hexacoordinated by two chloride ions in trans positions and 200 four water molecules $\left(\delta=1.22 \mathrm{~mm} \mathrm{~s}^{-1}\right){ }^{25}$ This strongly 201 suggests that, in acetonitrile, octahedral ferrous complexes are 202 formed with two chloride ions and four acetonitrile molecules 203 coordinated: $\left[\mathrm{FeCl}_{2}(S)_{4}\right](4 \mathrm{~S})\left(\mathrm{S}=\mathrm{NCCH}_{3}\right)$, which would 204 putatively coexist as both the trans and cis isomers. The 205 octahedral dication $\left[\mathrm{Fe}(S)_{6}\right]^{2+}$ was not detected under such 206 conditions. $^{26}$

207

The cyclic voltammetry of $\left[\mathrm{FeCl}_{2}(\mathrm{~S})_{4}\right](4 \mathrm{~S} ; 4 \mathrm{mM})$ in 208 acetonitrile (containing ${ }^{n} \mathrm{Bu}_{4} \mathrm{NBF}_{4}(0.3 \mathrm{M})$ as the supporting 209 electrolyte) exhibited several irreversible reduction peaks 210 (Figure 2a). One major reduction peak was observed at $E_{\mathrm{R} 1}^{\mathrm{P}} 211 \mathrm{f} 2$ $=-1.41 \mathrm{~V}$ versus the saturated calomel electrode (SCE), along 212 with two minor reduction peaks at +0.48 and $-1.92 \mathrm{~V}$. On the 213 reverse scan, a major oxidation peak was observed at $-0.048 \mathrm{~V}, 214$ with minor oxidation peaks at -0.35 and $+0.61 \mathrm{~V}$. This result 215 can be explained by considering the equilibrium between ionic 216 


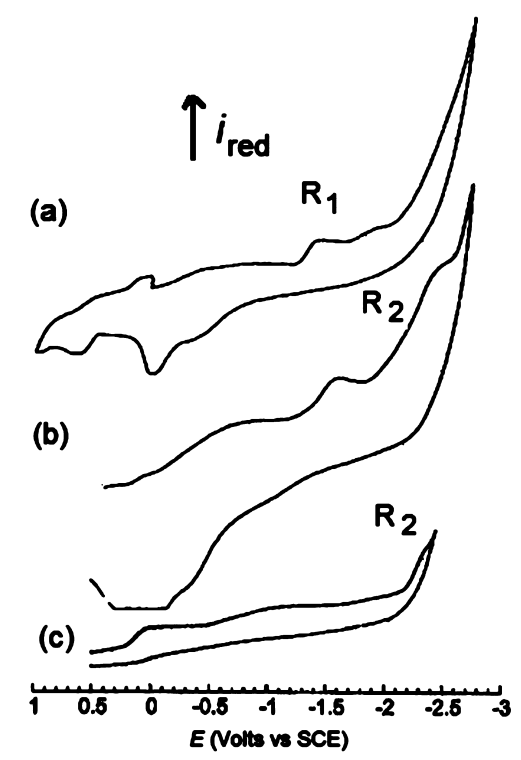

Figure 2. Cyclic voltammetry performed at a gold-disk electrode $(d=$ $1 \mathrm{~mm})$ at $22{ }^{\circ} \mathrm{C}$ in acetonitrile $(S)$ containing ${ }^{n} \mathrm{Bu}_{4} \mathrm{NBF}_{4}(0.3 \mathrm{M})$ as the supporting electrolyte: (a) Reduction of $\left[\mathrm{Fe}^{\mathrm{II}} \mathrm{Cl}_{2}(S)_{4}\right](4 \mathrm{~S} ; 4 \mathrm{mM})$ at a scan rate of $0.5 \mathrm{~V} \mathrm{~s}^{-1}$; (b) $\left[\mathrm{Fe}^{\mathrm{II}} \mathrm{Cl}_{2}(S)_{4}\right](4 \mathrm{~S} ; 4 \mathrm{mM})$ in the presence of $\mathrm{NaBH}_{4}$ (4 equiv) at a scan rate of $5 \mathrm{~V} \mathrm{~s}^{-1}$; (c) reduction of isolated $\left[\left(\eta^{1}-\mathrm{H}_{3} \mathrm{BH}\right) \mathrm{Fe}^{\mathrm{II}} \mathrm{Cl}(S)_{4}\right](5 ; 4 \mathrm{mM})$ at a scan rate of $0.5 \mathrm{~V} \mathrm{~s}^{-1}$.

217 species formed from $\left[\mathrm{FeCl}_{2}(S)_{4}\right](4 \mathrm{~S})$ in an acetonitrile 218 solution (Scheme 6). ${ }^{27,28}$ The position of the equilibrium is 219 expected to be sensitive to the concentration and the ionic 220 strength induced by the supporting electrolyte.

Scheme 6. Postulated Iron(II) Complexes Formed in Acetonitrile

$$
\begin{gathered}
{\left[\mathrm{Fe}^{\prime \prime} \mathrm{Cl}_{2}(S)_{4}\right]+\mathrm{nS} \rightleftarrows \quad\left[\mathrm{Fe}^{\prime \prime} \mathrm{Cl}_{(2-n)}(S)_{(4+n)}\right]^{\mathrm{n+}}+\mathrm{n} \mathrm{Cl}^{-}} \\
4 \mathrm{~S} \quad \mathrm{~S}=\mathrm{CH}_{3} \mathrm{CN} ; \mathrm{n}=0,1,2
\end{gathered}
$$

221 Characterization of the Iron(II) Complex Formed in 222 Situ from the Reaction of $\left[\mathrm{FeCl}_{2}(S)_{4}\right](4 \mathrm{~S})$ with $\mathrm{NaBH}_{4}$ in 223 Acetonitrile. The reaction of nonstabilized iron(II) and 224 iron(III) salts such as $\mathrm{FeBr}_{2}$ and $\mathrm{FeBr}_{3}$ by $\mathrm{NaBH}_{4}$ has been 225 explored by several groups, and the structure of the resulting 226 species was remarkably solvent dependent. For example, in the 227 presence of water in diethyl ether, the reduction of $\mathrm{FeBr}_{2}$ leads 228 to the formation of noncrystalline metallic $\mathrm{Fe}^{0}$, whereas in dry 229 diglyme borohydride-ligated iron(II) complexes such as $230\left[\mathrm{Fe}\left(\mathrm{BH}_{4}\right)_{2}(S)_{n}\right](S=$ diglyme $)$ are obtained, with no further 231 reduction of the metal occurring at temperatures lower than 65 $232{ }^{\circ} \mathrm{C} .{ }^{29}$ However, the analogous bis-borohydride complex proved 233 to be unstable in dry diethyl ether. ${ }^{30}$ Several well-defined 234 iron(II) borohydride complexes supported by various (PNP) 235 pincer ligands have been reported and characterized by X-ray 236 diffraction. $^{31}$ In some cases, the iron center features $\eta^{1}$ 237 coordination of the borohydride ligand ${ }^{31}$ or bridging $\mu_{2}, \eta^{1}: \eta^{1}$ $238 \mathrm{H}_{2} \mathrm{BH}_{2}$ moieties. ${ }^{31 \mathrm{~d}}$ Some of these complexes exhibited good 239 catalytic activities in ketone hydrogenation ${ }^{31 \mathrm{c}}$ and methanol 240 dehydrogenation. $^{32}$

241 The reaction of $\mathrm{FeCl}_{2}(S)_{4}(4 \mathrm{~S})$ with $\mathrm{NaBH}_{4}$ was monitored 242 by cyclic voltammetry. The reduction peaks of $\left[\mathrm{FeCl}_{2}(S)_{4}\right]$ 243 (4S) (Figure 2a) decreased upon addition of sodium 244 borohydride (up to 4 equiv). At the same time a new reduction 245 peak was observed at $E_{\mathrm{R} 2}^{\mathrm{P}}=-2.32 \mathrm{~V}$ (Figure $2 \mathrm{~b}$ ). The reduction peak $R_{2}$ was attributed to the formation of a new 246 complex that has been independently synthesized and 247 characterized to be the borohydride iron(II) complex $\left[\left(\mathrm{BH}_{4}\right)-248\right.$ $\mathrm{FeCl}(S) 4]$ (5) (Scheme 7) (vide infra for the characterization $249 \mathrm{~s} 7$ data).

Scheme 7. Synthesis of $\left[\left(\eta^{1}-\mathrm{H}_{3} \mathrm{BH}\right) \mathrm{FeCl}\left(\mathrm{NCCH}_{3}\right)_{4}\right]$ (5) by

Reaction of $\mathrm{NaBH}_{4}$ with $\left\{\mathrm{Fe}(\mu-\mathrm{Cl})_{2}\left(\mathrm{NCCH}_{3}\right)_{2}\right\}_{n}$ in Acetonitrile

$$
\underset{\text { solid (4) }}{\left\{\mathrm{Fe}(\mu-\mathrm{Cl})_{2}\left(\mathrm{NCCH}_{3}\right)_{2}\right\} \mathrm{n}} \stackrel{\mathrm{S}=\mathrm{CH}_{3} \mathrm{CN}}{\longrightarrow} \underset{4 \mathbf{S}}{\left[\mathrm{FeCl}_{2}(\mathrm{~S})_{4}\right]}
$$

$$
\underset{\mathrm{CH}_{3} \mathrm{CN}, \Delta, \mathrm{Ar}, 3 \mathrm{~h}}{\stackrel{\mathrm{NaBH}_{4} \text { (0.4 equiv) }}{\longrightarrow}} \quad\left[\begin{array}{c}
\left.\left.\eta^{1}-\mathrm{H}_{3} \mathrm{BH}\right) \mathrm{FeCl}(\mathrm{S})_{4}\right] \\
\mathbf{5}
\end{array}\right.
$$

The isolated complex $\left[\left(\eta^{1}-\mathrm{H}_{3} \mathrm{BH}\right) \mathrm{FeCl}(S)_{4}\right]$ (5) was 251 prepared as shown in Scheme 7. Reaction of dichlorobis- 252 (acetonitrile)iron(II) (4) with sodium borohydride ( 0.4 equiv) 253 in acetonitrile gave an orange-brown solid. This new complex 254 (5) was extremely air sensitive and thermally unstable, which 255 made its complete characterization difficult. If appropriate 256 precautions were not taken to maintain an inert environment, a 257 noticeable and rapid color change of the complex occurred, 258 from dull orange-brown to bright yellow. X-ray analysis 259 revealed that the bright yellow complex was hexakis- 260 (acetonitrile)iron(II) ( $\mu$-oxo)bis(trichloroiron(III)) ([Fe- 261 $\left.\left.\left(\mathrm{NCCH}_{3}\right)_{6}\right]\left[\mathrm{Cl}_{3} \mathrm{Fe}(\mu-\mathrm{O}) \mathrm{FeCl}_{3}\right]\right){ }^{33}$

The isolated complex $\left[\left(\eta^{1}-\mathrm{H}_{3} \mathrm{BH}\right) \mathrm{FeCl}(S)_{4}\right]$ (5) was 263 characterized by cyclic voltammetry. It exhibited the same 264 reduction peak at $E_{\mathrm{R} 2}^{\mathrm{P}}=-2.37 \mathrm{~V}$ (Figure 2c) as the complex 265 generated in situ from $4 \mathrm{~S}$ and $\mathrm{NaBH}_{4}$ (Figure 2b). The 266 reduction peak of $\mathbf{5}$ is irreversible at low scan rate $(v=0.5 \mathrm{~V} 267$ $\mathrm{s}^{-1}$, Figure $2 \mathrm{c}$ ), indicating that the electrogenerated complex $5^{-} 268$ is not stable on the time scale of the cyclic voltammetry, in 269 contrast to $\left[\mathrm{HFe}^{\mathrm{I}} \mathrm{Cl}(\mathrm{dppe})_{2}\right]^{-}\left(3^{-}\right){ }^{16}$ However, at a higher 270 scan rate $\left(v=5 \mathrm{~V} \mathrm{~s}^{-1}\right.$, shorter time scale), the reduction peak of 271 5 at $\mathrm{R}_{2}$ became partially reversible, suggesting the formation of 272 $\left[\left(\eta^{1}-\mathrm{H}_{3} \mathrm{BH}\right) \mathrm{Fe}^{\mathrm{I}} \mathrm{Cl}\left(\mathrm{NCCH}_{3}\right)_{4}\right]^{-}\left(\mathbf{5}^{-}\right)$, which is partially stable 273 on the time scale of this cyclic voltammogram (Figure $2 \mathrm{~b}$ ). 274

Monitoring the addition of two 1 equiv amounts in 275 succession of $\mathrm{NaBH}_{4}$ to $\left[\mathrm{FeCl}_{2}(S)_{4}\right](4 \mathrm{~S})$ in $\mathrm{CD}_{3} \mathrm{CN}$ by 276 ${ }^{11} \mathrm{~B}\left\{{ }^{1} \mathrm{H}\right\}$ NMR in the presence of ${ }^{n} \mathrm{Bu}_{4} \mathrm{NBPh}_{4}$ as an internal 277 reference revealed that no boron-containing byproducts (such 278 as $\mathrm{H}_{3} \mathrm{~B} \cdot \mathrm{NCCH}_{3}$ adducts) were formed. $\mathrm{NaBH}_{4}$ itself could not 279 be detected in the $+500 /-500 \mathrm{ppm}$ range. However, free 280 $\mathrm{NaBH}_{4}$ was observed as a singlet at $-41 \mathrm{ppm}$ for higher $\mathrm{NaBH}_{4} 281$ concentrations ( $>3$ equiv/mol of iron). The reaction of $\mathrm{NaBH}_{4} 282$ with $\left[\mathrm{FeCl}_{2}(S)_{4}\right](4 \mathrm{~S})$ in acetonitrile in the absence of any 283 additional coligand is therefore in stark contrast with the 284 formation of the diphosphine complex $\left[\mathrm{HFeCl}(\mathrm{dppe})_{2}\right]$ (3) 285 from $\mathrm{NaBH}_{4}$ and $\left[\mathrm{FeCl}_{2}(\mathrm{dppe})_{2}\right]$, which can be synthesized 286 and isolated. In the latter case, a stable terminal hydride is 287 indeed obtained, and hydroborane $\mathrm{BH}_{3}$ is released in the bulk, 288 as confirmed by the characterization of its dppe-ligated adduct 289 by ${ }^{31} \mathrm{P}$ NMR spectroscopy. ${ }^{16 \mathrm{~b}}$ This strongly suggests that no 290 free diamagnetic boron byproduct is released in the bulk during 291 the reaction of $\mathrm{NaBH}_{4}$ with $\left[\mathrm{FeCl}_{2}(S)_{4}\right](4 \mathrm{~S})$ in acetonitrile 292 and that at least one borohydride anion could act as a ligand to 293 a paramagnetic NMR-silent species. This hypothesis is 294 consistent with the work of Klabunde mentioned earlier, who 295 reported that $\mathrm{FeBr}_{2}$ reacted with an excess of $\mathrm{NaBH}_{4}$ in diglyme 296 
Table 2. Parameters Determined from the Simulations of the Mössbauer Spectra Shown in Figure $1^{a}$

\begin{tabular}{|c|c|c|c|c|c|c|}
\hline addition of $\mathrm{NaBH}_{4}$ & dite & volor & $\delta\left(\mathrm{mm} \mathrm{s}^{-1}\right)$ & $\Delta E_{\mathrm{Q}}\left(\mathrm{mm} \mathrm{s}^{-1}\right)$ & $\Gamma\left(\mathrm{mm} \mathrm{s}^{-1}\right)^{b}$ & rel area $(\%)$ \\
\hline \multirow[t]{3}{*}{ no ${ }^{c}$} & I & dark green & 1.31 & 3.22 & 0.37 & 67 \\
\hline & II & light green & 1.34 & 2.37 & 0.50 & 19 \\
\hline & III & orange & 0.30 & 0.70 & 0.60 & 13 \\
\hline \multirow[t]{3}{*}{ yes $^{d}$} & IV & dark blue & 1.25 & 2.90 & -0.35 & 43 \\
\hline & $\mathrm{V}$ & light blue & 1.18 & 2.23 & 0.53 & 34 \\
\hline & VI & red & 0.46 & 0.74 & 0.51 & 24 \\
\hline
\end{tabular}

${ }^{a}$ Uncertainties are $\pm 0.03 \mathrm{~mm} \mathrm{~s}^{-1}$ on the isomer shift $\delta, \pm 0.05 \mathrm{~mm} \mathrm{~s}^{-1}$ on the quadrupole splitting $\Delta E_{\mathrm{Q}}$, and $\pm 2 \%$ on the relative area. ${ }^{b}$ The Lorentzian line presents a full width at half-maximum (fwhm) denoted as $\Gamma$. A negative value indicates a Voigt line shape, which is the convolution of a $0.19 \mathrm{~mm} \mathrm{~s}^{-1}$ fwhm Lorentzian line with a Gaussian whose fwhm is the absolute value of $\Gamma$. ${ }^{c}$ Mössbauer spectrum shown in Figure 1a. ${ }^{d}$ Mössbauer spectrum shown in Figure $1 \mathrm{~b}$.

297 to give diglyme-stabilized bis-borohydride complexes such as $298\left[\mathrm{Fe}\left(\mathrm{BH}_{4}\right)_{2}(S)_{n}\right](S=$ diglyme $){ }^{29}$ Moreover, high-resolution 299 ESI mass spectrometry revealed that, after ionization, $\left[\left(\eta^{1}-\right.\right.$ $\left.\left.300 \mathrm{H}_{3} \mathrm{BH}\right) \mathrm{FeCl}(S)_{4}\right]$ (5) exhibited the same fragment ion $301\left[\mathrm{FeCl}(S)_{2}\right]^{+}$as 4 , resulting from the loss of a borohydride 302 fragment and two acetonitrile ligands (calcd 172.95634, found 303 172.95650). ${ }^{34}$ Taken together, these results suggest that, in the 304 presence of a moderate excess of $\mathrm{NaBH}_{4}$ in acetonitrile 305 solution, $\left[\mathrm{FeCl}_{2}(S)_{4}\right]$ (4S) reacts to form an iron(II) 306 borohydride complex such as $\left[\left(\eta^{1}-\mathrm{H}_{3} \mathrm{BH}\right) \mathrm{FeCl}(S)_{4}\right]$ (5) by 307 substitution of a single chloride ligand.

308 The IR spectrum of $\left[\left(\eta^{1}-\mathrm{H}_{3} \mathrm{BH}\right) \mathrm{FeCl}(S)_{n}\right]$ (5, solid phase, 309 Nujol) confirmed the $\eta^{1}$ coordination mode of the borohydride 310 ligand. Well-defined stretches characteristic of a transition311 metal-ligated $\eta^{1}$-borohydride anion were observed at 2429, 3122390 , and $2352 \mathrm{~cm}^{-1}\left(\nu_{\mathrm{BH} 3}\right)$ and $\left.2042 \mathrm{~cm}^{-1}\left(\nu_{\mathrm{Fe}-\mathrm{H}-\mathrm{B}}\right)\right)^{31 \mathrm{a}}$ The $313 \mathrm{BH}_{3}$ deformation band could not be assigned precisely due to 314 the presence of other signals in the $900-1100 \mathrm{~cm}^{-1}$ area (see 315 the Supporting Information). No signal characteristic of a 316 terminal $\mathrm{Fe}-\mathrm{H}$ bond vibration in the $1800-2000 \mathrm{~cm}^{-1}$ range 317 (usual range for the $\mathrm{M}-\mathrm{H}$ bond vibration) could be detected, 318 thus excluding the formation of a terminal iron hydride. These 319 data are in good agreement with previous reports for $\left(\eta^{1}\right.$ 320 borohydrido)iron(II) species by Koehne $\mathrm{e}^{31 \mathrm{~d}}$ and Field. ${ }^{31 \mathrm{~b}}$ 321 However, it should be noted that almost all of the reported 322 iron(II) borohydride or terminal hydride complexes accom323 modate a low-spin configuration.

324 More structural insights into the nature of this borohydride 325 species under solvation conditions were gained by Mössbauer 326 spectroscopy on frozen solutions, starting from ${ }^{57} \mathrm{Fe}$-enriched 327 complexes. Figure $1 \mathrm{~b}$ shows the zero-field Mössbauer spectrum 328 recorded at $80 \mathrm{~K}$ on a $0.05 \mathrm{M}$ acetonitrile solution of ${ }^{57} \mathrm{FeCl}_{2}$ 329 after the addition of excess $\mathrm{NaBH}_{4}$. The addition of 18 or 53 330 equiv of $\mathrm{NaBH}_{4}$ leads to identical spectra. Accordingly, only the 331 spectrum with 53 equiv is shown. The lines are quite broad; 332 however, this spectrum significantly differs from that recorded 333 for $\left[\mathrm{FeCl}_{2}(S)_{4}\right](4 \mathrm{~S})$ (Figure 1a). A reduced separation of the 334 two more intense lines, now at 0 and $2.8 \mathrm{~mm} \mathrm{~s}^{-1}$ versus -0.3 335 and $3.0 \mathrm{~mm} \mathrm{~s}^{-1}$ for $\mathbf{4 S}$, is observed. In addition, a new line is 336 detected at $0.7 \mathrm{~mm} \mathrm{~s}^{-1}$. The slight shift of the high-velocity 337 pattern indicates that the starting $\mathrm{Fe}^{\mathrm{II}}$ species has reacted with $338 \mathrm{NaBH}_{4}$ and that new high-spin $\mathrm{Fe}^{\mathrm{II}}$ species are generated.

339 The spectrum shown in Figure $1 \mathrm{~b}$ was then simulated. In 340 order to reproduce the asymmetric profile of the high-velocity 341 line, three doublets must be considered. The simulation is 342 shown in Figure $1 b$, and the parameters are given in Table 2. 343 Two doublets (IV and V) present isomeric shift values lying 344 between 1.1 and $1.3 \mathrm{~mm} \mathrm{~s}^{-1}\left(\delta_{\mathrm{IV}}=1.25 \mathrm{~mm} \mathrm{~s}^{-1}, \Delta E_{\mathrm{Q} I V}=2.90\right.$ $\mathrm{mm} \mathrm{s}^{-1}(43 \%)$ and $\delta_{\mathrm{V}}=1.18 \mathrm{~mm} \mathrm{~s}^{-1}, \Delta E_{\mathrm{Q}, \mathrm{V}}=2.23 \mathrm{~mm} \mathrm{~s}^{-1} 345$ $(34 \%))$, which correspond to high-spin ferrous ions accom- 346 modating an octahedral environment, these sites accounting for 347 $77 \%$ of the total iron content. The isomeric shift value 348 associated with the third doublet (VI) is much lower $\left(\delta_{\mathrm{IV}}=349\right.$ $0.46 \mathrm{~mm} \mathrm{~s}^{-1}$ ), which renders this doublet more difficult to 350 assign. Because borohydride was added in great excess, a 351 reasonable hypothesis is that it is associated with a reduced 352 form of iron. This is in agreement with the cyclic voltammo- 353 gram recorded after addition of 50 equiv of $\mathrm{NaBH}_{4}$ (see the 354 Supporting Information). A broad oxidation peak is detected at 355 $E^{\mathrm{p}} \mathrm{O}=+0.2 \mathrm{~V}$ vs SCE, indicating the chemical reduction of $\mathrm{Fe}^{\mathrm{II}} 356$ to metallic $\mathrm{Fe}^{0}$. The same peak is also observed on the reverse 357 scan in Figure $2 \mathrm{a}$ and corresponds to the oxidation of the 358 electrogenerated reduced species adsorbed at the electrode and 359 formed upon electroreduction of $\left[\mathrm{FeCl}_{2}(S)_{4}\right](4 \mathrm{~S})$.

DFT calculations were performed to gain further insights 361 into the high-spin ferrous species $\mathbf{5}$ generated by the reaction of 362 $\mathrm{NaBH}_{4}$ with $\left[\mathrm{FeCl}_{2}(S)_{4}\right](4 \mathrm{~S})$. Alternative structures were also 363 computed for comparison (Scheme 8). Because the isomer $364 \mathrm{~s} 8$ shifts of the doublets labeled IV and V (Table 2) are 365 significantly lower than those of the starting species (doublets 366 I and II, Table 2), it is reasonable to postulate the substitution 367 of one ligand by a stronger $\sigma$ donor: namely, borohydride or 368 hydride. Calculations were performed on several model 369 complexes (see the Supporting Information). The negatively 370

Scheme 8. Distribution of (a) Mono- and (b) Bis-

Borohydrido $\mathrm{Fe}^{\mathrm{II}}$ Species Obtained by Reaction of Excess $\mathrm{NaBH}_{4}$ with $\left[\mathrm{FeCl}_{2}(S)_{4}\right](4 S)$ in Acetonitrile

a) formation of mono-borohydrides:

$$
\left[\mathrm{FeCl}_{2}(\mathrm{~S})_{4}\right] \underset{-\mathrm{NaCl}}{\stackrel{\mathrm{NaBH}_{4}}{\longrightarrow}}\left[\mathrm{H}_{3} \mathrm{BH}-\mathrm{FeCl}(\mathrm{S})_{4}\right] \mathbf{5} \text { (cis or trans) }
$$

b) formation of bis-borohydrides:

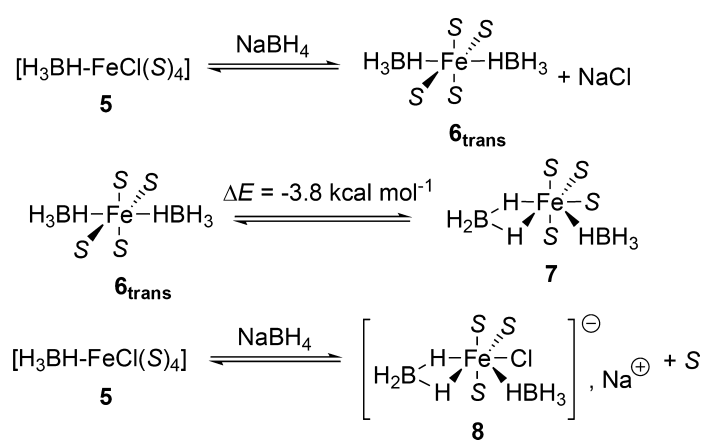


371 charged ligands $\left(\mathrm{Cl}^{-}, \mathrm{BH}_{4}^{-}, \mathrm{H}^{-}\right)$may be in the cis or trans 372 positions, and the borohydrido ligand may coordinate in the $\eta^{1}$ 373 or $\kappa^{2}$ mode. Since $\mathrm{NaBH}_{4}$ is present in great excess, the 374 coordination of two borohydride ligands was also considered. A 375 selection of calculated isomer shift values is given in Table 3.

Table 3. Calculated Isomer Shifts $(\delta)$ for Several Relevant High-Spin $\mathrm{Fe}^{\mathrm{II}}$ Borohydrides $^{a}$

\begin{tabular}{llcc} 
label & \multicolumn{1}{c}{ complex } & $\begin{array}{c}\rho_{0}(\mathrm{calcd}) \\
\left(\mathrm{e} \mathrm{a}_{0}{ }^{-3}\right)\end{array}$ & $\begin{array}{c}\delta(\mathrm{calcd}) \\
\left(\mathrm{mm} \mathrm{s}^{-1}\right)\end{array}$ \\
$\mathbf{5}_{\text {trans }}$ & trans $-\left[\left(\eta^{1}-\mathrm{H}_{3} \mathrm{BH}\right) \mathrm{FeCl}\left(\mathrm{NCCH}_{3}\right)_{4}\right]$ & 11816.89 & 1.20 \\
$\mathbf{5}_{\text {cis }}$ & cis- $\left[\left(\eta^{1}-\mathrm{H}_{3} \mathrm{BH}\right) \mathrm{FeCl}\left(\mathrm{NCCH}_{3}\right)_{4}\right]$ & 11816.85 & 1.21 \\
$\mathbf{6}_{\text {trans }}$ & $\operatorname{trans}^{1}\left[\left(\eta^{1}-\mathrm{H}_{3} \mathrm{BH}\right)_{2} \mathrm{Fe}\left(\mathrm{NCCH}_{3}\right)_{4}\right]$ & 11817.08 & 1.13 \\
7 & {$\left[\left(\kappa^{2}(\mathrm{H}, \mathrm{H})-\mathrm{H}_{2} \mathrm{BH}_{2}\right)\left(\eta^{1}-\mathrm{H}_{3} \mathrm{BH}\right)\right.$} & 11816.76 & 1.27 \\
& $\left.\mathrm{Fe}(\mathrm{NCCH})_{4}\right]$ & & \\
8 & {$\left[\left(\kappa^{2}(\mathrm{H}, \mathrm{H})-\mathrm{H}_{2} \mathrm{BH}_{2}\right)\left(\eta^{1}-\mathrm{H}_{3} \mathrm{BH}\right)\right.$} & 11816.69 & 1.27
\end{tabular}

${ }^{a}$ The calculated isomer shift values are deduced from the correlation curve established in the Supporting Information.

376 Solvated complex $\mathbf{5}$ was tentatively assigned as the 377 borohydrido complex $\left[\left(\eta^{1}-\mathrm{H}_{3} \mathrm{BH}\right) \mathrm{FeCl}\left(\mathrm{NCCH}_{3}\right)_{4}\right]$ in the 378 solid phase (Scheme 7). Simulations of the Mössbauer 379 parameters of the trans and cis isomers of $\left[\left(\eta^{1}-\mathrm{H}_{3} \mathrm{BH}\right) \mathrm{FeCl}-\right.$ $\left.380\left(\mathrm{NCCH}_{3}\right)_{4}\right]$ (5) were performed (Scheme 8a). Complexes $381 \boldsymbol{5}_{\text {trans }}$ and $\boldsymbol{5}_{\text {cis }}$ were found to be almost isoenergetic $(\Delta E \approx 1$ $\left.382 \mathrm{kcal} \mathrm{mol}^{-1}\right)$, with similar nuclear parameters $\left(\delta=1.20 \mathrm{~mm} \mathrm{~s}^{-1}\right.$ $383\left(\boldsymbol{5}_{\text {trans }}\right) ; \delta=1.21 \mathrm{~mm} \mathrm{~s}^{-1}\left(\boldsymbol{5}_{\text {cis }}\right)$; Table 3$)$. It was found that the 384 parent hydrides $\left[\mathrm{HFeCl}\left(\mathrm{NCCH}_{3}\right)_{4}\right]$ led to smaller values of the 385 isomer shift (ca. $1.1 \mathrm{~mm} \mathrm{~s}^{-1}$ ), in agreement with $\mathrm{H}^{-}$having 386 stronger $\sigma$ donating properties in comparison $\mathrm{BH}_{4}^{-}$(see the 387 Supporting Information).

388 Therefore, computed parameters of monoborohydrido 389 complexes $\boldsymbol{5}_{\text {trans }}$ and $\boldsymbol{5}_{\text {cis }}$ (Table 3 , and Scheme 8a) reproduce 390 the simulation of doublet $\mathrm{V}$ in the experimental spectrum well 391 (Figure $1 \mathrm{~b}$ and Table 2). Due to the high borohydride to iron 392 ratio (18 or 53 equiv) in the Mössbauer experiments, bis393 borohydrido complexes can also be obtained. Complexes $\left[\left(\eta^{1}\right.\right.$ $\left.\left.394 \mathrm{H}_{3} \mathrm{BH}\right)_{2} \mathrm{Fe}\left(\mathrm{NCCH}_{3}\right)_{4}\right]$ (6) can be formed by substitution of the 395 remaining chloride anion of 5 by a second borohydride. DFT 396 calculations show that 6 evolve(s) toward the more stable 397 complex $7\left[\left(\kappa^{2}(H, H)-\mathrm{H}_{2} \mathrm{BH}_{2}\right)\left(\eta^{1}-\mathrm{H}_{3} \mathrm{BH}\right) \mathrm{Fe}\left(\mathrm{NCCH}_{3}\right)_{4}\right](\Delta E=$ $398-3.8 \mathrm{kcal} \mathrm{mol}^{-1}$, Scheme $\left.8 \mathrm{~b}\right)$. In complex 7 , the steric pressure 399 in the meridional plane containing five ligands leads to longer 400 metal-ligand bonds and therefore to an electronic density at 401 the ${ }^{57} \mathrm{Fe}$ nucleus smaller than that for the octahedral species $402 \boldsymbol{5}_{\text {trans }}$ and $\boldsymbol{5}_{\text {cis. }}$. Consequently, the corresponding isomer shift is 403 higher $\left(\delta=1.27 \mathrm{~mm} \mathrm{~s}^{-1}, 7\right.$; Table 3$)$. Analogously, $\left[\left(\kappa^{2}(H, H)\right.\right.$ $\left.\left.404 \mathrm{H}_{2} \mathrm{BH}_{2}\right)\left(\eta^{1}-\mathrm{H}_{3} \mathrm{BH}\right) \mathrm{FeCl}\left(\mathrm{NCCH}_{3}\right)_{3}\right]^{-}$(8), formed from 5 via 405 substitution of an acetonitrile molecule by $\mathrm{BH}_{4}{ }^{-}$, was computed 406 (Scheme 8b). Complex 8 gave a similarly high computed 407 isomer shift $\left(\delta=1.27 \mathrm{~mm} \mathrm{~s}^{-1}, \mathbf{8}\right.$; Table 3$)$ to 7 . Therefore, the 408 doublet IV in the spectrum (Figure $1 \mathrm{~b}$ and Table 2) can be 409 explained by the formation of sterically constrained bis410 borohydrido species such as 7 and 8, which exhibit isomer 411 shifts higher than those of $\mathbf{5}$.

412 Computation of mono and bis iron(II) borohydride nuclear 413 parameters can explain the general trend observed in the 414 Mössbauer experimental spectrum. ${ }^{35}$ Moreover, the formation 415 of bis-borohydrido species can explain the fast formation of 416 reduced oxidation states leading to the observation of the 417 doublet VI in Figure 1b. However, due to the broadness of the 418 experimental signals, it can be anticipated that several structurally similar isomers (or other species with similar 419 nuclear parameters) coexist in solution.

Iron(II) Hydride versus Iron(II) Borohydride Com- 421 plexes. As stated in the previous section, there is a major 422 difference in the electronic properties of the $\mathrm{Fe}^{\mathrm{II}}-\mathrm{H}$ bond in 423 the well-defined diphosphine-ligated complex $\left[\mathrm{HFeCl}(\mathrm{dppe})_{2}\right] 424$ (3) and in borohydride acetonitrile-ligated complexes such as 425 $\left[\left(\eta^{1}-\mathrm{H}_{3} \mathrm{BH}\right) \mathrm{FeCl}\left(\mathrm{NCCH}_{3}\right)_{4}\right](5)$. The former is a low-spin $\mathrm{Fe}^{\mathrm{II}} 426$ terminal hydride, whereas the latter is a high-spin $\mathrm{Fe}^{\mathrm{II}}{ }_{427}$ borohydride. This difference is well reflected by DFT 428 calculations. The computation of the enthalpy of formation 429 of the dppe-stabilized borohydride trans- $\left[\left(\eta^{1}-\mathrm{H}_{3} \mathrm{BH}\right) \mathrm{FeCl}-430\right.$ (dppe $\left.)_{2}\right]\left(\mathbf{3}^{\prime}{ }_{\text {trans }}\right)$ from trans-[HFeCl(dppe $\left.)_{2}\right]\left(\mathbf{3}_{\text {trans }}\right)$ and the 431 $\mathrm{H}_{3} \mathrm{~B} \cdot \mathrm{NCCH}_{3}$ adduct clearly shows that the terminal hydride 3432 is more stable than the corresponding borohydride $3^{\prime}{ }_{\text {trans }}(\Delta E 433$ $=10.7 \mathrm{kcal} \mathrm{mol}^{-1}$; Scheme 9a). This equilibrium is the opposite $434 \mathrm{~s} 9$

Scheme 9. DFT-Computed Equilibria between Hydrides and Borohydrides for Complexes (a) 3 and $3^{\prime}$ and (b) 5 and $5^{\prime a}$

$$
\begin{aligned}
& \text { a) }\left[\mathrm{HFeCl}(\text { dppe })_{2}\right]+\mathrm{H}_{3} \mathrm{~B} \cdot \mathrm{S} \rightleftharpoons\left[\eta^{1}-\mathrm{H}_{3} \mathrm{BHFeCl}(\text { dppe })_{2}\right]+\mathrm{S} \\
& 3(0.0) \quad 3 \mathbf{3}^{\prime}(10.7)
\end{aligned}
$$

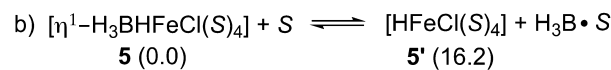

${ }^{a}$ All complexes were computed as trans isomers. Values in parentheses stand for the energies in $\mathrm{kcal} \mathrm{mol}^{-1}$.

for the acetonitrile-ligated system, which is shown to be far 435 more stabilized in the borohydride form, with trans- $\left[\left(\eta^{1}-436\right.\right.$ $\left.\left.\mathrm{H}_{3} \mathrm{BH}\right) \mathrm{FeCl}\left(\mathrm{NCCH}_{3}\right)_{4}\right]\left(\mathbf{5}_{\text {trans }}\right)$ stabilized by ca. $\Delta E=16.2 \mathrm{kcal} 437$ $\mathrm{mol}^{-1}$ with respect to the corresponding hydride trans- 438 $\left[\mathrm{HFeCl}\left(\mathrm{NCCH}_{3}\right)_{4}\right]\left(\mathbf{5}^{\prime}{ }_{\text {trans }} ;\right.$ Scheme $\left.9 \mathrm{~b}\right)$.

An analysis of the electronic population of trans-[HFeCl- 440 $\left.(\text { dppe })_{2}\right]\left(3_{\text {trans }}\right)$ by natural bond orbital $(\mathrm{NBO})$ theory shows 441 that there is a strong delocalization of the $\sigma(\mathrm{Fe}-\mathrm{H})$ molecular 442 orbital into the antibonding $\sigma^{*}(\mathrm{Fe}-\mathrm{P})$ MOs. The analysis is 443 drastically different for the acetonitrile-ligated complex trans- 444 $\left[\mathrm{HFeCl}\left(\mathrm{NCCH}_{3}\right)_{4}\right]\left(\mathbf{5}_{\text {trans }}^{\prime}\right)$, where no significant delocaliza- 445 tion of the $\sigma(\mathrm{Fe}-\mathrm{H})$ molecular orbital into the acetonitrile 446 ligands is observed. Consistent with this observation, all of the 447 spin density is located on the iron center in trans-[HFeCl- 448 $\left.\left(\mathrm{NCCH}_{3}\right)_{4}\right]\left(\mathbf{5}^{\prime}{ }_{\text {trans }}\right)$ (computed Mulliken spin density on iron 449 4.00, which is the expected theoretical value for a high-spin $\mathrm{Fe}^{\mathrm{II}} 450$ ion), and the iron-ligated acetonitrile ligands remain mostly 451 neutral (average computed NBO charge for each acetonitrile 452 ligand $q=+0.04(\mathrm{el})$, showing that no charge transfer occurs 453 from the $\mathrm{Fe}^{\mathrm{II}}-\mathrm{H}$ moiety.

Chlorotetrakis(acetonitrile)iron(II) Borohydride Com- 455 plex $\mathbf{5}$ as Precatalyst for Reactions of Unsaturated 456 Haloacetals. $\left[\left(\eta^{1}-\mathrm{H}_{3} \mathrm{BH}\right) \mathrm{Fe}^{\mathrm{II}} \mathrm{Cl}\left(\mathrm{NCCH}_{3}\right)_{4}\right]$ (5) was tested as 457 a suitable precatalyst for reaction with haloacetals (1), as shown 458 in Scheme 10.

Indeed, $\left[\left(\eta^{1}-\mathrm{H}_{3} \mathrm{BH}\right) \mathrm{Fe}^{\mathrm{II}} \mathrm{Cl}\left(\mathrm{NCCH}_{3}\right)_{4}\right]$ (5) catalyzed the 460 reaction of both iodoacetal $\left(\mathbf{1}_{\mathrm{I}}\right)$ and bromoacetal $\left(\mathbf{1}_{\mathrm{Br}}\right) 461$ substrates in the presence of 1.0 equiv of $\mathrm{NaBH}_{4}$ (Table 4), $462 \mathrm{t} 4$ in contrast to $\left[\mathrm{HFeCl}(\mathrm{dppe})_{2}\right]$ (3), which only mediated the 463 reaction of iodoacetal $\left(\mathbf{1}_{\mathrm{I}}\right)$. Complete conversion and good 464 yields were obtained for iodoacetals $\mathbf{1}_{\mathrm{I}}$ and $\mathbf{1}_{\mathrm{I} n \operatorname{Pr}}$ (entries 1 and 465 3 , Table 4). In the case of $\mathbf{1}_{\mathrm{IMe}}$ a moderate yield (46\%) of the 466 bicyclic product $\left(2_{\mathrm{diMe}}\right)$ was obtained along with $19 \%$ recovery 467 of the starting material (entry 5). The unsubstituted 468 bromoacetal $\left(\mathbf{1}_{\mathrm{Br}}\right)$ was completely consumed in the reaction, 469 and $57 \%$ of bicyclic product $\left(\mathbf{2}_{\mathbf{H}}\right)$ was obtained (entry 2, Table 470 
Scheme 10. Reaction of Haloacetals 1 in the Presence of $\left[\left(\eta^{1}-\mathrm{H}_{3} \mathrm{BH}\right) \mathrm{Fe}^{\mathrm{II}} \mathrm{Cl}\left(\mathrm{NCCH}_{3}\right)_{4}\right](5)$ and $\mathrm{NaBH}_{4}$

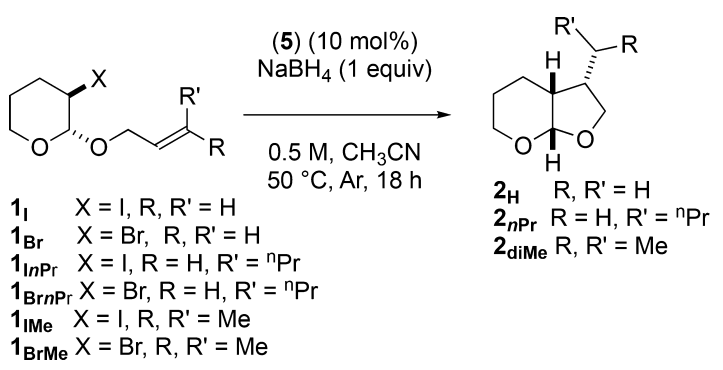

Table 4. Reactivity of Haloacetals 1 in the Presence of $\left[\left(\boldsymbol{\eta}^{1}\right.\right.$ $\left.\left.\mathrm{H}_{3} \mathrm{BH}\right) \mathrm{Fe}^{\mathrm{II}} \mathrm{Cl}\left(\mathrm{NCCH}_{3}\right)_{4}\right](5)(10 \mathrm{~mol} \%)$ and Sodium Borohydride ( 1 equiv) ${ }^{a}$

\begin{tabular}{ccc} 
entry & substrate & yield of $\mathbf{2}(\%)($ recovered $\mathbf{1}(\%))[\mathrm{dr}]$ \\
\hline 1 & $\mathbf{1}_{\mathrm{I}}$ & $77(0)[88: 12]$ \\
2 & $\mathbf{1}_{\mathrm{Br}}$ & $57(0)[86: 14]$ \\
3 & $\mathbf{1}_{\mathrm{I} n \mathbf{P r}}$ & $70(0)[82: 18]$ \\
4 & $\mathbf{1}_{\mathrm{Br} n \operatorname{Pr}}$ & $38(38)[81: 19]$ \\
5 & $\mathbf{1}_{\mathrm{IMe}}$ & $46(19)[66: 34]$ \\
6 & $\mathbf{1}_{\mathrm{BrMe}}$ & $23(55)[65: 35]$
\end{tabular}

${ }^{a}$ Reaction conditions: $1\left(1.0 \mathrm{mmol}, 0.5 \mathrm{M}\right.$ in $\left.\mathrm{CH}_{3} \mathrm{CN}\right),\left[\left(\eta_{1^{-}}\right.\right.$ $\left.\left.\mathrm{H}_{3} \mathrm{BH}\right) \mathrm{Fe}^{\mathrm{II}} \mathrm{Cl}\left(\mathrm{NCCH}_{3}\right)_{4}\right]$ (5) (10 mol \%), $\mathrm{NaBH}_{4}$ (1 equiv), $50{ }^{\circ} \mathrm{C}$, $18 \mathrm{~h}$.

$4714)$. Substituted bromoacetals $\left(\mathbf{1}_{\mathrm{BrnPr}}\right.$ and $\left.\mathbf{1}_{\mathrm{BrMe}}\right)$ were reactive, 472 albeit with incomplete conversion, giving the bicyclic products 473 in $38 \%$ yield $\left(\mathbf{2}_{n \mathrm{Pr}}\right.$, entry 4 , Table 4$)$ and $23 \%$ yield $\left(\mathbf{2}_{\text {diMe }}\right.$, entry 4746 ), respectively.

475 Mechanistic Studies: Exploring Reactivity Differences. 476 This raised an important question about the ability of the 477 iron(II) monohydride or borohydride complexes, ligated by 478 either phosphorus ligands (3) or acetonitrile ligands (5), to act 479 as precatalysts for the reaction of bromoacetal $\left(\mathbf{1}_{\mathrm{Br}}\right)$.

480 Cyclic voltammetry had been used to evidence the catalytic 481 turnover of the active iron(I) anionic hydride catalyst $482\left[\mathrm{HFe}^{\mathrm{I}} \mathrm{Cl}(\mathrm{dppe})_{2}\right]^{-}\left(3^{-}\right)$in the presence of iodoacetal $\left(\mathbf{1}_{\mathrm{I}}\right){ }^{16}$ 483 Thus, the catalytic activity of $\left[\left(\eta^{1}-\mathrm{H}_{3} \mathrm{BH}\right) \mathrm{Fe}^{\mathrm{I}} \mathrm{Cl}\left(\mathrm{NCCH}_{3}\right)_{4}\right]^{-}$ $484\left(5^{-}\right)$in the presence of haloacetals $\left(\mathbf{1}_{\mathrm{I}}\right.$ and $\left.\mathbf{1}_{\mathrm{Br}}\right)$ was also tested 485 by electrochemistry. The reduction potential of iodoacetal $\left(\mathbf{1}_{\mathrm{I}}\right)$ in acetonitrile was measured at $E_{\text {red }}^{\mathrm{P}}=-2.5 \mathrm{~V}$ vs. SCE at a scan 486 rate of $0.5 \mathrm{~V} \mathrm{~s}^{-1}$. In contrast, the reduction potential of 487 bromoacetal $\left(\mathbf{1}_{\mathrm{Br}}\right)$ could not be measured, as the substrate was 488 not reduced before the solvent $\left(E_{\text {red }}^{\mathrm{P}}=-2.7 \mathrm{~V}\right.$ vs. SCE). As 489 shown in Figure 3a, in the presence of iodoacetal $\left(\mathbf{1}_{\mathrm{I}}\right)$, the $490 \mathrm{f} 3$ reduction peak $\mathrm{R}_{2}$ of $\left[\left(\eta^{1}-\mathrm{H}_{3} \mathrm{BH}\right) \mathrm{Fe}^{\mathrm{II}} \mathrm{Cl}\left(\mathrm{NCCH}_{3}\right)_{4}\right]$ (5) 491 increases with each aliquot of substrate $(0-10$ equiv, Figure 492 $3 \mathrm{a})$. Therefore, the anionic species $\left[\left(\eta^{1}-\mathrm{H}_{3} \mathrm{BH}\right) \mathrm{Fe}^{\mathrm{I}} \mathrm{Cl}-493\right.$ $\left.\left(\mathrm{NCCH}_{3}\right)_{4}\right]^{-}\left(5^{-}\right)$(generated by electrochemical reduction 494 of $\left.\left[\left(\eta^{1}-\mathrm{H}_{3} \mathrm{BH}\right) \mathrm{Fe}^{\mathrm{II}} \mathrm{Cl}\left(\mathrm{NCCH}_{3}\right)_{4}\right](\mathbf{5})\right)$ activates iodoacetal $\left(\mathbf{1}_{\mathrm{I}}{ }_{495}\right.$ by electron transfer. This in turn regenerates $\left[\left(\eta^{1}-\mathrm{H}_{3} \mathrm{BH}\right)-496\right.$ $\left.\mathrm{Fe}^{\mathrm{II}} \mathrm{Cl}\left(\mathrm{NCCH}_{3}\right)_{4}\right]$ (5), and a catalytic current was observed. 497 This reveals that the interaction of $\left[\left(\eta^{1}-\mathrm{H}_{3} \mathrm{BH}\right) \mathrm{Fe}^{\mathrm{I}} \mathrm{Cl}-498\right.$ $\left.\left(\mathrm{NCCH}_{3}\right)_{4}\right]^{-}\left(\mathbf{5}^{-}\right)$with $\mathbf{1}_{\mathrm{I}}$ is faster than its decomposition on 499 the time scale of cyclic voltammetry.

The procedure was repeated in the presence of bromoacetal 501 $\left(\mathbf{1}_{\mathrm{Br}}\right)$. A noticeable catalytic effect in the presence of $\mathbf{1}_{\mathrm{Br}}$ was 502 observed, as shown in Figure $3 \mathrm{~b}$ ( $0-12$ equiv). This result 503 provides strong evidence that the acetonitrile ligated $\left[\left(\eta^{1}-504\right.\right.$ $\left.\left.\mathrm{H}_{3} \mathrm{BH}\right) \mathrm{Fe}^{\mathrm{II}} \mathrm{Cl}\left(\mathrm{NCCH}_{3}\right)_{4}\right]$ (5) furnishes the catalytic species 505 $\left[\left(\eta^{1}-\mathrm{H}_{3} \mathrm{BH}\right) \mathrm{Fe}^{\mathrm{I}} \mathrm{Cl}\left(\mathrm{NCCH}_{3}\right)_{4}\right]^{-}\left(\mathbf{5}^{-}\right)$able to activate both $\mathbf{1}_{\mathrm{I}} 506$ and $\mathbf{1}_{\mathrm{Br}}$. The turnover was lower for $\mathbf{1}_{\mathrm{Br}}$ than for $\mathbf{1}_{\mathrm{I}}$ (compare 507 the catalytic currents in parts $b$ and $c$ of Figures 3, respectively). 508

No catalytic current at $\mathrm{R}_{3}$ was observed when [HFeCl- 509 (dppe $)_{2}$ (3) was reduced in the presence of increasing amount 510 of $\mathbf{1}_{\mathrm{Br}}(1-6$ equiv, Figure $3 \mathrm{c})$, in contrast to the case for [ $\left(\eta^{1}-511\right.$ $\left.\left.\mathrm{H}_{3} \mathrm{BH}\right) \mathrm{Fe}^{\mathrm{II}} \mathrm{Cl}\left(\mathrm{NCCH}_{3}\right)_{4}\right]$ (5) (Figure 3b). Therefore, anionic 512 $\left[\left(\eta^{1}-\mathrm{H}_{3} \mathrm{BH}\right) \mathrm{Fe}^{\mathrm{I}} \mathrm{Cl}\left(\mathrm{NCCH}_{3}\right)_{4}\right]^{-}\left(\mathbf{5}^{-}\right)$promotes the reduction of 513 $\mathbf{1}_{\mathrm{Br}}$ in contrast to $\left[\mathrm{HFe}^{\mathrm{I}} \mathrm{Cl}(\mathrm{dppe})_{2}\right]^{-}\left(3^{-}\right)$, in agreement with 514 the experimental observations. This shows that the ligand 515 structure (hydride versus borohydride) strongly affects the 516 reactivity of the anionic iron(I) complex with $\mathbf{1}_{\mathrm{Br}}$. 517

These results have interesting mechanistic implications to 518 explain the higher reactivity of bromoacetal $\left(\mathbf{1}_{\mathrm{Br}}\right)$ in the 519 presence of $\left[\left(\eta^{1}-\mathrm{H}_{3} \mathrm{BH}\right) \mathrm{Fe}^{\mathrm{II}} \mathrm{Cl}\left(\mathrm{NCCH}_{3}\right)_{4}\right](5)$ versus $\left[\mathrm{HFe}^{\mathrm{II}} \mathrm{Cl}-520\right.$ (dppe $\left.)_{2}\right]$ (3).

The rate of electron transfer of $\left[\left(\eta^{1}-\mathrm{H}_{3} \mathrm{BH}\right) \mathrm{Fe}^{\mathrm{I}} \mathrm{Cl}-522\right.$ $\left.\left(\mathrm{NCCH}_{3}\right)_{4}\right]^{-}\left(5^{-}\right)$or $\left[\mathrm{HFe}^{\mathrm{I}} \mathrm{Cl}(\mathrm{dppe})_{2}\right]^{-}\left(3^{-}\right)$to haloacetals 523 is controlled by the potential gap $(\Delta E)$ between the reduction 524 potential of the haloacetals and the oxidation potential of the 525 anionic iron(I) (boro)hydride complexes. This potential gap is 526
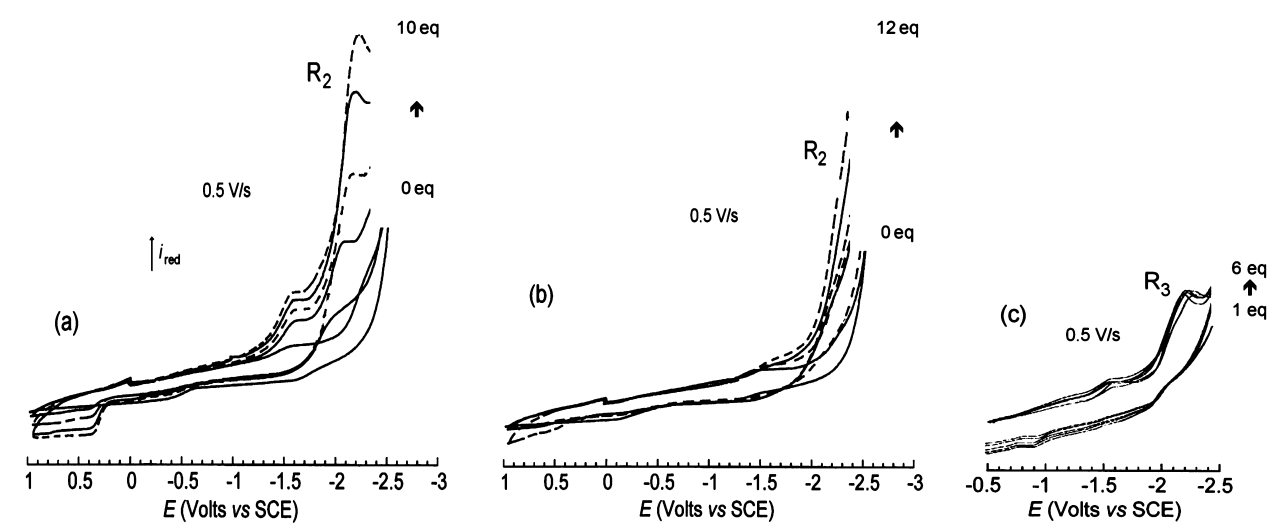

Figure 3. Cyclic voltammetry performed at a gold-disk electrode $(d=1 \mathrm{~mm})$ at $22{ }^{\circ} \mathrm{C}$ in acetonitrile containing ${ }^{n} \mathrm{Bu}_{4} \mathrm{NBF}_{4}(0.3 \mathrm{M})$ as the supporting electrolyte at a scan rate of $0.5 \mathrm{~V} \mathrm{~s}^{-1}$ : (a) reduction of $\left[\left(\eta^{1}-\mathrm{H}_{3} \mathrm{BH}\right) \mathrm{Fe}^{\mathrm{II}} \mathrm{Cl}\left(\mathrm{NCCH}_{3}\right)_{4}\right](4 \mathrm{mM})$ in the presence of increasing amounts of $\mathbf{1}_{\mathrm{I}}(0$ and 4 equiv, solid lines; 6 equiv, dashed line; 8 equiv, solid line; 10 equiv, dashed line); (b) reduction of $\left[\left(\eta^{1}-\mathrm{H}_{3} \mathrm{BH}\right) \mathrm{Fe}^{\mathrm{II}} \mathrm{Cl}\left(\mathrm{NCCH}_{3}\right)_{4}\right](4 \mathrm{mM})$ in the presence of increasing amounts of $\mathbf{1}_{\mathrm{Br}}\left(0\right.$ and 8 equiv, solid lines; 4 and 12 equiv, dashed lines); (c) reduction of $\left[\mathrm{HFe}^{\mathrm{II}} \mathrm{Cl}(\mathrm{dppe})_{2}\right](4 \mathrm{mM})$ in the presence of increasing amounts of $\mathbf{1}_{\mathrm{Br}}$ (1-6 equiv, solid lines). 


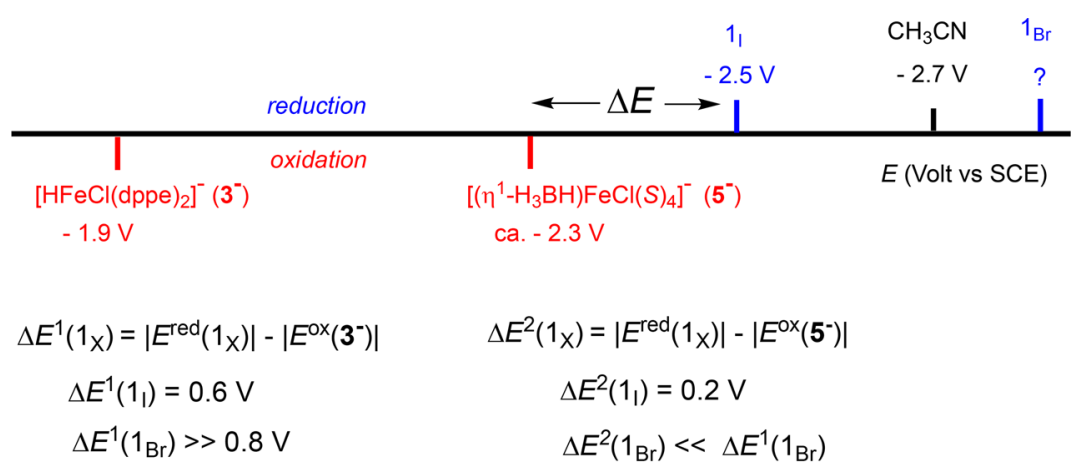

reactivity order

$\left[\mathrm{HFeCl}(\mathrm{dppe})_{2}\right]^{-}\left(3^{-}\right) \quad \ll \quad\left[\left(\eta^{1}-\mathrm{H}_{3} \mathrm{BH}\right) \mathrm{FeCl}(S)_{4}\right]^{-}\left(\mathbf{5}^{-}\right)$

Figure 4. Cyclic voltammetry data used to explain the difference in reactivity of anionic complexes $\mathbf{3}^{-}$and $\mathbf{5}^{-}$with iodo- and bromoacetals $\left(\mathbf{1}_{\mathrm{X}}\right)(\mathrm{X}=$ $\mathrm{I}, \mathrm{Br})$.

527 crucial to the outcome of the reaction: indeed, the lower the 528 potential gap, the faster the reaction. ${ }^{36}$

529 As stated earlier, $\mathbf{1}_{\mathrm{I}}$ is more easily reduced than $\mathbf{1}_{\mathrm{Br}}$ at $-2.5 \mathrm{~V}$ 530 and more negative than $-2.7 \mathrm{~V}$, respectively (Figure 4). $\left.531 \mathrm{HFe}^{\mathrm{I}} \mathrm{Cl}(\mathrm{dppe})_{2}\right]^{-}\left(3^{-}\right)$is less easily oxidized $(-1.9 \mathrm{~V})^{16 \mathrm{a}}$ than $532\left[\left(\eta^{1}-\mathrm{H}_{3} \mathrm{BH}\right) \mathrm{Fe}^{\mathrm{I}} \mathrm{Cl}\left(\mathrm{NCCH}_{3}\right)_{4}\right]^{-}\left(5^{-}\right)$(estimated to be ca. -2.3 $533 \mathrm{~V}$ ) (Figure 4).

$534 \quad\left[\mathrm{HFe}^{\mathrm{I}} \mathrm{Cl}(\mathrm{dppe})_{2}\right]^{-}\left(3^{-}\right)$reacts with $\mathbf{1}_{\mathrm{I}}$ because of the low 535 potential gap, $\Delta E^{1}\left(\mathbf{1}_{\mathrm{I}}\right)=0.6 \mathrm{~V}$, which permits a fast reaction 536 (Figure 4$)$. The reaction with $\mathbf{1}_{\mathrm{I}}$ is even faster with $\left[\left(\eta^{1}\right.\right.$ $\left.\left.537 \mathrm{H}_{3} \mathrm{BH}\right) \mathrm{Fe}^{\mathrm{I}} \mathrm{Cl}(S)_{4}\right]^{-}\left(\mathbf{5}^{-}\right)$because the potential gap $\Delta E^{2}\left(\mathbf{1}_{\mathrm{I}}\right)$ is 538 even lower $(0.2 \mathrm{~V})$ (Figure 4$)$.

539 The potential gap $\Delta E^{1}\left(\mathbf{1}_{\mathrm{Br}}\right)$ between $\left[\mathrm{HFe}^{\mathrm{I}} \mathrm{Cl}(\mathrm{dppe})_{2}\right]^{-}\left(3^{-}\right)$ 540 and $\mathbf{1}_{\mathrm{Br}}$ is larger than $0.8 \mathrm{~V}$. This explains why the catalytic 541 reaction does not proceed when $\left[\mathrm{HFe}^{\mathrm{II}} \mathrm{Cl}(\text { dppe })_{2}\right](3)$ is used 542 as the precatalyst. The potential gap $\Delta E^{2}\left(\mathbf{1}_{\mathrm{Br}}\right)$ between $5^{-}$and $543 \mathbf{1}_{\mathrm{Br}}$ is smaller than $\Delta E^{1}\left(\mathbf{1}_{\mathrm{Br}}\right)\left(\Delta E^{2}\left(\mathbf{1}_{\mathrm{Br}}\right)<\Delta E^{1}\left(\mathbf{1}_{\mathrm{Br}}\right)\right.$, Figure 4), 544 and therefore $\left[\left(\eta^{1}-\mathrm{H}_{3} \mathrm{BH}\right) \mathrm{Fe}^{\mathrm{I}} \mathrm{Cl}(S)_{4}\right]^{-}\left(\mathbf{5}^{-}\right)$can activate $\mathbf{1}_{\mathrm{Br}}$ and 545 the catalytic reaction proceeds. In conclusion, the acetonitrile 546 ligand renders the corresponding catalytically active species $547\left(5^{-}\right)$far more active than the phosphine ligand $\left(3^{-}\right)$. This 548 clearly demonstrates the importance of the ligand in 549 determining the outcome of the catalytic reaction.

550 Mechanism. The results of the catalytic reactions and 551 subsequent mechanistic investigation performed on $\left[\left(\eta^{1}-\right.\right.$ $\left.\left.552 \mathrm{H}_{3} \mathrm{BH}\right) \mathrm{Fe}^{\mathrm{II}} \mathrm{Cl}\left(\mathrm{NCCH}_{3}\right)_{4}\right]$ (5) provides evidence for the active 553 catalyst, the anionic iron(I) borohydride species $\left[\left(\eta^{1}-\mathrm{H}_{3} \mathrm{BH}\right)\right.$ $\left.554 \mathrm{Fe}^{\mathrm{I}} \mathrm{Cl}\left(\mathrm{NCCH}_{3}\right)_{4}\right]^{-}\left(5^{-}\right)$(Figure 5). The latter is formed from 555 the iron(II) borohydride precatalyst 5 , either by electro556 chemical means or by $\mathrm{NaBH}_{4}$. Activation of $\mathrm{RX}\left(\mathbf{1}_{\mathrm{X}}, \mathrm{X}=\mathrm{I}, \mathrm{Br}\right)$ 557 by $5^{-}$via electron transfer generates the radical $\mathrm{R}^{\circ}$ involved in 558 the cyclization process. Hydrogen atom transfer to form the 559 final cyclized product $\mathrm{R}^{\prime} \mathrm{H}$ occurs either directly from $\mathrm{BH}_{4}{ }^{-}$or 560 from $\left[\left(\eta^{1}-\mathrm{H}_{3} \mathrm{BH}\right) \mathrm{Fe}^{\mathrm{II}} \mathrm{Cl}\left(\mathrm{NCCH}_{3}\right)_{4}\right]$ (5) (vide infra for the 561 computational studies that model the final step). ${ }^{37}$

562

\section{CONCLUSIONS}

563 In conclusion it is established that the structure and reactivity of 564 the active iron catalyst in the cyclization of unsaturated iodo565 and bromoacetals is directly related to the ligand environment 566 (acetonitrile versus dppe). The iron(II) borohydride $\left[\left(\eta^{1}-\right.\right.$ $\left.\left.567 \mathrm{H}_{3} \mathrm{BH}\right) \mathrm{FeCl}\left(\mathrm{NCCH}_{3}\right)_{4}\right]$ (5) has been synthesized, and its 568 catalytic and redox properties have been compared to those of 569 the reported iron(II) hydride $\left[\mathrm{HFeCl}(\text { dppe })_{2}\right](3){ }^{16}$ As

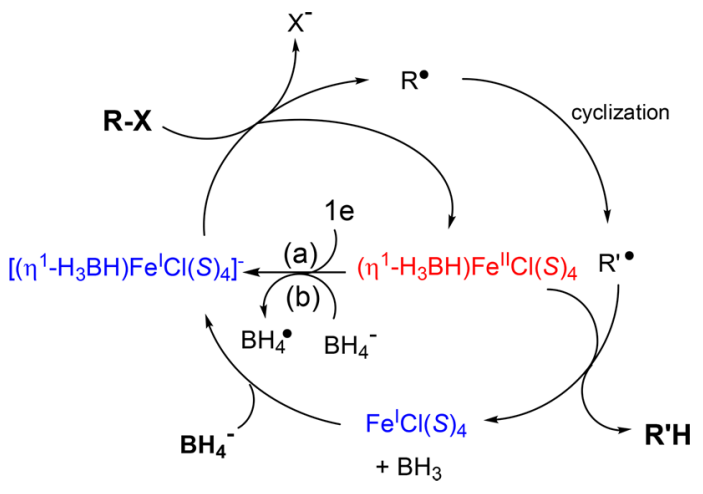

Figure 5. Mechanistic role of the active anionic iron(I) borohydride complex (blue) generated either (a) by electrochemical reduction or (b) by reduction by $\mathrm{NaBH}_{4}$ of the iron(II) borohydride complex (red).

observed by cyclic voltammetry, the anionic iron(I) complex 570 $\left[\left(\eta^{1}-\mathrm{H}_{3} \mathrm{BH}\right) \mathrm{FeCl}\left(\mathrm{NCCH}_{3}\right)_{4}\right]^{-}\left(\mathbf{5}^{-}\right)$is able to activate both 571 iodo- and bromoacetals, in contrast to $\left[\mathrm{HFeCl}(\mathrm{dppe})_{2}\right]^{-}\left(3^{-}\right), 572$ which can only activate the iodoacetal. This result is in 573 agreement with the synthetic reactions in which the precatalyst 574 $\left[\left(\eta^{1}-\mathrm{H}_{3} \mathrm{BH}\right) \mathrm{FeCl}\left(\mathrm{NCCH}_{3}\right)_{4}\right]$ (5) mediates the cyclization of 575 the bromoacetal, while $\left[\mathrm{HFeCl}(\mathrm{dppe})_{2}\right]$ (3) cannot. The 576 potential gap between the reduction potential of the haloacetal 577 and the oxidation potential of the anionic hydrido $\left(3^{-}\right)$or 578 borohydrido $\left(5^{-}\right)$iron(I) complex is crucial for the reaction 579 outcome. When the potential gap is too large, the SET is too 580 slow and the catalytic reaction does not occur. This rationalizes 581 the role of the ligand which is responsible for the formation of 582 either hydrido iron(II)/iron(I) complexes (ligand dppe) or 583 borohydrido iron(II)/iron(I) complexes (ligand acetonitrile), 584 which possess different redox properties.

585

These findings emphasize new perspectives to be considered 586 in the design of new radical mediators. The fine tailoring of the 587 ligand on the metal center is key to the success of such an 588 approach. Work is underway to use this understanding to 589 identify potential ligand candidates and validate them as 590 efficient precatalysts for a wider range of radical reactions. 591

\section{EXPERIMENTAL SECTION}

592

General Considerations. All reactions were carried out in oven- 593 dried glassware under an argon atmosphere using standard Schlenk 594 
595 techniques. Reaction solvents (acetonitrile and dichloromethane) were 596 degassed with argon and dried using a PureSolv Micro Solvent 597 Purification System (Innovative Technology) by percolation through a 598 column packed with neutral alumina under a positive pressure of 599 argon. Other solvents were dried and distilled prior to use by literature 600 methods. All solvents were further degassed via freeze/pump/thaw 601 cycles with argon prior to use. Column chromatography was 602 performed using Merck Geduran SI $60 \AA$ silica gel $(35-70 \mu \mathrm{m}){ }^{2}$ 603 Purification was performed using Sigma-Aldrich $58 \AA$ neutral alumina 604 (Brockman I, activated) as required. All substrates were filtered 605 through neutral alumina prior to use. Iron(II) dichloride (anhydrous 606 beads, 10 mesh, 99.99\%) and sodium borohydride (99.99\%) were 607 purchased from Sigma-Aldrich. These reagents were stored in the 608 glovebox and used as received. NMR spectra were recorded on a 609 Bruker AV400 or Avance III spectrometer fitted with either a QNP or $610 \mathrm{BBFO}$ probe and calibrated using undeuterated acetonitrile $\left(\delta_{\mathrm{H}} 1.94\right.$ $611 \mathrm{ppm}$ and $\left.\delta_{\mathrm{C}} 118.26\right)$ or chloroform $\left(\delta_{\mathrm{H}} 7.26 \mathrm{ppm}\right.$ and $\left.\delta_{\mathrm{C}} 77.16 \mathrm{ppm}\right)$ 612 as internal references. High-resolution ESI mass spectra were recorded 613 using a FT-ICR mass spectrometer ( 7 T hybrid FTICR Solarix 614 spectrometer, Bruker Daltonik $\mathrm{GmbH}$ ) combined with an ion funnel 615 geometry to transfer the formed ions. Cyclic voltammetry $(\mathrm{CV})$ was 616 performed with a laboratory-made potentiostat and a PAR Model 175 617 waveform generator. The working electrode was a steady gold disk ( $d$ $618=1 \mathrm{~mm}$ ), the counter electrode a platinum wire (ca. $0.2 \mathrm{~cm}^{2}$ apparent 619 area), and the reference a saturated calomel electrode. Cyclic 620 voltammograms were recorded with a Nicolet 3091 digital 621 oscilloscope. All experiments were carried out under argon.

622 Typical Procedure for the Synthesis of Iron Complexes. 623 trans-Hydridochlorobis $\{1,2$-bis(diphenylphosphino)ethane $\}$ iron(II), 624 trans-[HFeCl(dppe $\left.)_{2}\right]$ (3).. ${ }^{17,38}$ Iron(II) dichloride (160 mg, $\left.1.3 \mathrm{mmol}\right)$ 625 and bis(diphenylphosphino)ethane $(1.00 \mathrm{~g}, 2.5 \mathrm{mmol})$ were placed in 626 a Schlenk flask in the glovebox, and then ethanol $(15 \mathrm{~mL})$ was added 627 under argon. The mixture was stirred vigorously for $10 \mathrm{~min}$ and then 628 heated to $50{ }^{\circ} \mathrm{C}$. Sodium borohydride $(29 \mathrm{mg}, 0.76 \mathrm{mmol})$ was placed 629 in a separate Schlenk tube in the glovebox, ethanol $(12 \mathrm{~mL})$ was added 630 under argon, and the solution was stirred for $10 \mathrm{~min}$. The sodium 631 borohydride solution was added over $15 \mathrm{~min}$ to the iron mixture under 632 a counter current of argon. After $2 \mathrm{~h}$ the reaction mixture had turned 633 bright red-purple with both red and white precipitates. The reaction 634 mixture was filtered, and the filtrate was washed with distilled water 635 (dried and degassed, $2 \mathrm{~mL}$ ) and ethanol (dried and degassed, $2 \mathrm{~mL}$ ) 636 and then dried under vacuum. Benzene (dried and degassed, $20 \mathrm{~mL}$ ) 637 was added (not all precipitate dissolved) and the solution was filtered 638 under argon. The solvent was removed to give a red-purple solid (550 $639 \mathrm{mg}, 49 \%)$, which was dried under vacuum. The complex was stable in 640 the glovebox for more than 6 months. The title compound had 641 spectral properties identical with those previously reported.

642 Dichlorobis(acetonitrile)iron(II) (4). ${ }^{39}$ Iron(II) chloride (1.00 g, 7.9 $643 \mathrm{mmol})$ was placed in a Schlenk tube in the glovebox. Acetonitrile (5 $644 \mathrm{~mL}$ ) was added under argon, and the reaction mixture was heated to 645 reflux for $3 \mathrm{~h}$. The reaction mixture was cooled to room temperature, 646 resulting in the precipitation of a solid. The solvent was removed 647 under argon, and the solid was washed with toluene (dried and 648 degassed, $2 \mathrm{~mL}$ ) and hexane (dried and degassed, $2 \mathrm{~mL}$ ) and then 649 dried under vacuum to give colorless fine crystals ( $1.40 \mathrm{~g}, 85 \%)$. The 650 complex was stable in the glovebox for more than 6 months. Crystals 651 suitable for single-crystal X-ray crystallography were obtained directly 652 from the mother liquor and corresponded to the data previously 653 reported.

654 Chlorotetrakis(acetonitrile)iron(II) Borohydride (5). Dichlorobis655 (acetonitrile)iron(II) $(4 ; 360 \mathrm{mg}, 1.7 \mathrm{mmol}$ ) was placed in a Schlenk 656 flask in the glovebox, acetonitrile $(15 \mathrm{~mL})$ was added under argon, and 657 the mixture was stirred for $10 \mathrm{~min}$. Sodium borohydride $(30 \mathrm{mg}, 0.76$ $658 \mathrm{mmol}$ ) was placed in a separate Schlenk tube in the glovebox, 659 acetonitrile $(12 \mathrm{~mL})$ was added under argon, and the solution was 660 stirred vigorously for $10 \mathrm{~min}$. The sodium borohydride solution was 661 added over $15 \mathrm{~min}$ to the iron mixture under a counter current of 662 argon. After $3 \mathrm{~h}$ the reaction mixture had turned dark orange with 663 some precipitate observed. The reaction mixture was filtered under argon, the filtrate was concentrate,d and the resulting orange-brown 664 solid $(255 \mathrm{mg}, 56 \%)$ was dried under vacuum and stored under argon. 665

Typical Procedure for the Synthesis of Haloacetal Sub- 666 strates. A mixture of $\mathrm{N}$-halosuccinimide $(76 \mathrm{mmol})$ and alcohol $(74667$ $\mathrm{mmol}$ ) in dichloromethane $(40 \mathrm{~mL})$ was cooled to $-10^{\circ} \mathrm{C}$, and then 668 3,4-dihydro-2 $H$-pyran $(6.8 \mathrm{~mL}, 75 \mathrm{mmol})$ was added dropwise under 669 argon. The reaction mixture was warmed to room temperature over 3670 $\mathrm{h}$ and stirred at this temperature overnight. The reaction mixture was 671 diluted with dichloromethane $(40 \mathrm{~mL})$ and washed with saturated 672 sodium thiosulfate $(3 \times 20 \mathrm{~mL})$. The combined aqueous phase was 673 extracted with dichloromethane $(3 \times 20 \mathrm{~mL})$, the combined organic 674 phase was washed with brine $(20 \mathrm{~mL})$ and dried (phase separation 675 paper), and the solvent was removed in vacuo. The residue was 676 purified by column chromatography (20\% diethyl ether/80\% pentane) 677 to afford the title compound. The product was filtered through neutral 678 alumina prior to use.

Typical Procedure for Cyclization of Haloacetal Substrates. 680 The iron complex $(0.1 \mathrm{mmol})$ and reducing agent were placed in a 681 screw-cap tube in the glovebox (the tube was capped with a Suba- 682 Seal). Acetonitrile $(1.5 \mathrm{~mL}$ ) was added under argon, and the mixture 683 was stirred for ca. $15 \mathrm{~min}$ at room temperature. A solution of 684 haloacetal $(1.0 \mathrm{mmol})$ in acetonitrile $(0.5 \mathrm{~mL})$ was added under argon, 685 the Suba-Seal was replaced by a screw cap, and the reaction mixture 686 was heated to $50{ }^{\circ} \mathrm{C}$ overnight. The reaction mixture was cooled to 687 room temperature and quenched with water $(20 \mathrm{~mL})$, and the aqueous 688 phase was extracted with dichloromethane $(3 \times 20 \mathrm{~mL})$. The 689 combined organic phase was washed with brine $(30 \mathrm{~mL})$ and dried 690 (phase separation paper), and the solvent was removed in vacuo. The 691 residue was purified by flash chromatography (5-20\% diethyl ether/ 692 pentane).

Electrochemical Analyses. Cyclic voltammetry (CV) was 694 performed in a three-electrode cell connected to a Schlenk line 695 (under argon) at room temperature with a laboratory-made 696 potentiostat and a PAR Model 175 waveform generator. The working 697 electrode was a steady gold disk $(d=1 \mathrm{~mm})$ and the counter electrode 698 a platinum wire (ca. $0.2 \mathrm{~cm}^{2}$ apparent area). The reference was a 699 saturated calomel electrode (SCE) separated from the solution by a 700 bridge filled with tetrabutylammonium tetrafluoroborate in acetonitrile 701 solution $(0.3 \mathrm{M}, 2 \mathrm{~mL})$. The same solution $(0.3 \mathrm{M}, 12 \mathrm{~mL})$ was used 702 as the solvent in the electrochemical cell for all $\mathrm{CV}$ experiments 703 reported herein. Cyclic voltammograms were recorded with a Nicolet 704 3091 digital oscilloscope. All experiments were carried out under 705 argon.

General Procedure A: Determination of Redox Potentials. 707 Substrate $(0.048 \mathrm{mmol}, 4 \mathrm{mM})$ was placed in the electrochemical 708 cell containing a solution of tetrabutylammonium tetrafluoroborate in 709 acetonitrile $(0.3 \mathrm{M}, 12 \mathrm{~mL})$. The $\mathrm{CV}$ was performed immediately after 710 mixing, at a scan rate of $0.5 \mathrm{~V} \mathrm{~s}^{-1}$.

General Procedure B: Electrochemical Reduction of Iron 712 Complexes in the Presence of Sodium Borohydride. The iron(II) 713 complex $(0.048 \mathrm{mmol}, 4 \mathrm{mM})$ was placed in the cell, the mixture was 714 stirred briefly, and the CV was performed immediately at a scan rate of 715 0.5 or $5 \mathrm{~V} \mathrm{~s}^{-1}$. Sodium borohydride $(0.048 \mathrm{mmol})$ was added, the 716 mixture was stirred briefly, and the CV was performed immediately. 717

General Procedure C: Electrochemical Reduction of Iron 718 Complexes in the Presence of Haloacetal. The iron complex 719 $(0.048 \mathrm{mmol}, 4 \mathrm{mM})$ was placed in the cell, the mixture was stirred 720 briefly, and the CV was performed immediately at a scan rate of $0.5 \mathrm{~V} 721$ $\mathrm{s}^{-1}$. The haloacetal $(0.048 \mathrm{mmol})$ was added, the mixture was stirred 722 briefly, and the $\mathrm{CV}$ was performed immediately. Additional aliquots of 723 haloacetal ( 1 equiv) were added, and the CV was performed 724 immediately, up to a total of 4-12 equiv depending on substrate. 725

Mössbauer Spectroscopy. Mössbauer spectra were recorded on 726 powder samples of natural-abundance ${ }^{57} \mathrm{Fe}$ compounds or on 727 acetonitrile solutions starting with fully enriched ${ }^{57} \mathrm{FeCl}_{2}$ In the 728 synthesis of isotopically enriched ${ }^{57} \mathrm{FeCl}_{2}$, elemental $94 \%$-enriched 729 ${ }^{57} \mathrm{Fe}$ was heated under a dry in situ generated chlorine atmosphere at 730 $350{ }^{\circ} \mathrm{C}$ over $15 \mathrm{~min}$. Dry chlorine was obtained by adding dropwise 731 anhydrous sulfuric acid into a commercial bleach solution; the 732 resulting chlorine gas was then dried by bubbling into sulfuric acid 733 
734 (98\%). The experiments were performed using a horizontal trans735 mission $4 \mathrm{~K}$ closed cycle refrigerator system from Janis and SHI and a $736100 \mathrm{mCi}$ source of ${ }^{57} \mathrm{Co}(\mathrm{Rh})$ as previously described. ${ }^{40}$ All velocity 737 scales and isomer shifts are referred to the metallic iron standard at 738 room temperature. Analysis of the data was performed with the 739 software WMOSS4 Mössbauer spectral analysis software (www. 740 wmoss.org, 2009-2015).

741 DFT Calculations. Simulations of the nuclear parameters were 742 performed using the ORCA code (v. 3.0.3) at a DFT level (BP86, 743 Ahlrich's TZVP set for all atoms except $\mathrm{Fe}$, which was treated using 744 the CP(PPP) set). See the Supporting Information for additional 745 details and the corresponding references. Mössbauer parameters can 746 be easily evaluated using straightforward DFT techniques, which allow 747 the computation of the electronic density at the ${ }^{57} \mathrm{Fe}$ nucleus, denoted $748 \rho_{0}$ (in units of $\mathrm{e}_{0}{ }^{-3}$, where $\mathrm{a}_{0}$ is the Bohr radius). A reliable estimation 749 of the isomer shift $(\delta)$ can be obtained with a linear extrapolation from $750 \rho_{0}{ }^{41}$ To do so, a benchmark of high-spin and low-spin Fe ${ }^{\mathrm{II}}$ complexes 751 has been used to calibrate the chosen level of theory. Computation of 752 the quadrupolar split was not performed herein because this parameter 753 is highly dependent on the symmetry of the occupied electronic levels. 754 For several complexes in the following benchmark, the experimental 755 value of $\Delta E_{\mathrm{Q}}$ could not be reproduced with a satisfying accuracy. 756 Minor differences between the optimized geometries and the 757 experimental structures can induce strong discrepancies between the 758 experimental and calculated values of $\Delta E_{\mathrm{Q}} \cdot{ }^{42}$ Computation of the 759 Mössbauer parameters was performed using ORCA 3.0.3 software. $^{41}$ 760 The BP86 functional ${ }^{43}$ was used, with Ahlrich's TZVP basis set ${ }^{44}$ for 761 all atoms except $\mathrm{Fe}$, which was described using the $\mathrm{CP}(\mathrm{PPP})$ enlarged 762 basis set. $^{45}$

\section{ASSOCIATED CONTENT}

\section{S Supporting Information}

765 The Supporting Information is available free of charge on the 766 ACS Publications website at DOI: 10.1021/acs.organo767 met.7b00603.

768 Experimental details and procedures, spectral data,

769 electrochemical analysis, Mössbauer spectroscopy, and 770 computational analysis (PDF)

\section{AUTHOR INFORMATION}

\section{Corresponding Authors}

773 *E-mail for L.F.: louis.fensterbank@upmc.fr.

774 *E-mail for A.J.: Anny.Jutand@ens.fr.

775 *E-mail for G.L.: Guillaume.Lefevre@cea.fr.

776 *E-mail for C.O.: cyril.ollivier@upmc.fr.

\section{ORCID 우}

778 Sara H. Kyne: 0000-0002-6995-9311

779 Etienne Derat: 0000-0002-8637-2707

780 Louis Fensterbank: 0000-0003-0001-7120

781 Guillaume Lefevre: 0000-0001-9409-5861

\section{Present Address}

${ }_{783}{ }^{\perp}$ S.H.K.: School of Chemistry, University of Lincoln, Joseph 784 Banks Laboratories, Lincoln LN6 7DL, U.K.

785 Notes

786 The authors declare no competing financial interest.

\section{ACKNOWLEDGMENTS}

788 The research leading to these results received funding from the 789 European Union Seventh Framework Programme ([FP7/2007790 2013]) under grant agreement $\mathrm{n}^{\circ}$ [2988969] (S.H.K.). This 791 work was also supported by the UPMC, ENS, CNRS, IUF 792 (L.F.), ANR-10-BLAN-0701 CREDOX and ANR-12-BS07$7930031 \mathrm{CoCaCoLight.} \mathrm{Technical} \mathrm{assistance} \mathrm{was} \mathrm{generously}$ 794 offered by FR 2769. Drs. Lise-Marie Chamoreau, Elsa Caytan,
Denis Lesage, and Sébastien Blanchard are acknowledged for 795 providing technical assistance and useful discussions.

\section{REFERENCES}

(1) Jahn, U.; Heinrich, M.; Gansäuer, A. Top. Curr. Chem. 2011, 320, 798 191-322.

(2) Kochi, J. K. Acc. Chem. Res. 1974, 7, 351-360.

(3) (a) Iqbal, J.; Bhatia, B.; Nayyar, N. K. Chem. Rev. 1994, 94, 519- 801 564. (b) Gansäuer, A.; Bluhm, H. Chem. Rev. 2000, 100, 2771-2788. 802 (4) (a) Norton, J. R.; Sowa, J. Chem. Rev. 2016, 116, 8315-8317. 803 and references cited therein (b) Jordan, A. J.; Lalic, G.; Sadighi, J. P. 804 Chem. Rev. 2016, 116, 8318-8372.

(5) Takami, K.; Mikami, S.; Yorimitsu, H.; Shinokubo, H.; Oshima, 806 K. Tetrahedron 2003, 59, 6627-6635.

(6) (a) Inoue, K.; Sawada, A.; Shibata, I.; Baba, A. J. Am. Chem. Soc. 808 2002, 124, 906-907. (b) Hayashi, N.; Shibata, I.; Baba, A. Org. Lett. 809 2004, 6, 4981-4983. (c) Baba, A.; Shibata, I. Chem. Rec. 2005, 5, 323- 810 335. 811

(7) Fujita, K.; Nakamura, T.; Yorimitsu, H.; Oshima, K. J. Am. Chem. 812 Soc. 2001, 123, 3137-3138.

(8) Liu, Y.; Schwartz, J. Tetrahedron 1995, 51, 4471-4482. 813

(9) (a) Kharasch, M. S.; Fields, E. K. J. Am. Chem. Soc. 1941, 63, 815 2316-2320. (b) Tamura, M.; Kochi, J. K. J. Am. Chem. Soc. 1971, 93, 816 1487-1489.

(10) Felkin, H.; Meunier, B. Nouv. J. Chim. 1977, 1, 281-282. 818 (11) (a) Hayashi, Y.; Shinokubo, H.; Oshima, K. Tetrahedron Lett. 819 1998, 39, 63-66. (b) For a review on iron-catalyzed hydro- 820 functionalization, see: Greenhalgh, M. D.; Jones, A. S.; Thomas, S. P. 821 ChemCatChem 2015, 7, 190-222.

(12) (a) Freidlina, R. K.; Velichko, F. K. Synthesis 1977, 1977, 145- 823 154. (b) Hilt, G.; Bolze, P.; Harms, K. Chem. - Eur. J. 2007, 13, 4312- 824 4325. (c) Zhang, S.-Y.; Tu, Y.-Q.; Fan, C.-A.; Zhang, F.-M.; Shi, L. 825 Angew. Chem., Int. Ed. 2009, 48, 8761-8765. (d) Prateeptongkum, S.; 826 Jovel, I.; Jackstell, R.; Vogl, N.; Weckbecker, C.; Beller, M. Chem. 827 Commun. 2009, 1990-1992. (e) Vallée, F.; Mousseau, J.; Charette, A. 828 B. J. Am. Chem. Soc. 2010, 132, 1514-1516. (f) Shirakawa, E.; Masui, 829 S.; Narui, R.; Watabe, R.; Ikeda, D.; Hayashi, T. Chem. Commun. 2011, 830 47, 9714-9716. (g) Pratsch, G.; Anger, C. A.; Ritter, K.; Heinrich, M. 831 Chem. - Eur. J. 2011, 17, 4104-4108. (h) Ito, S.; Itoh, T.; Nakamura, 832 M. Angew. Chem., Int. Ed. 2011, 50, 454-457.

(13) For iron(II) or iron(III) hydride systems see: (a) Taniguchi, T.; 834 Goto, N.; Nishibata, A.; Ishibashi, H. Org. Lett. 2010, 12, 112-115. 835 (b) Leggans, E. K.; Barker, T. J.; Duncan, K. K.; Boger, D. L. Org. Lett. 836 2012, 14, 1428-1431. (c) Barker, T. J.; Boger, D. L. J. Am. Chem. Soc. 837 2012, 134, 13588-13591. (d) Lo, J. C.; Yabe, Y.; Baran, P. S. J. Am. 838 Chem. Soc. 2014, 136, 1304-1307. (e) Lo, J. C.; Gui, J.; Yabe, Y.; Pan, 839 C.-M.; Baran, P. S. Nature 2014, 516, 343-348. (f) Gui, J.; Pan, C.-M.; 840 Jin, Y.; Qin, T.; Lo, J. C.; Lee, B. J.; Spergel, S. H.; Mertzman, M. E.; 841 Pitts, W. J.; La Cruz, T. E.; Schmidt, M. A.; Darvatkar, N.; Natarajan, S. 842 R.; Baran, P. S. Science 2015, 348, 886-891. (g) Dao, H. T.; Li, C.; 843 Michaudel, Q.; Maxwell, B. D.; Baran, P. S. J. Am. Chem. Soc. 2015, 844 137, 8046-8049. (h) Lo, J. C.; Kim, D.; Pan, C.-M.; Edwards, J. T.; 845 Yabe, Y.; Gui, J.; Qin, T.; Gutiérrez, S.; Giacoboni, J.; Smith, M. W.; 846 Holland, P. L.; Baran, P. S. J. Am. Chem. Soc. 2017, 139, 2484-2503. 847 (i) For a review on iron catalysis, see: Bauer, I.; Knölker, H.-J. Chem. 848 Rev. 2015, 115, 3170-3387.

(14) Nakazawa, H.; Itazaki, M. Top. Organomet. Chem. 2011, 33, 27- 850 81.

(15) (a) Marks, T. J.; Kolb, J. R. Chem. Rev. 1977, 77, 263-293. 852 (b) Maity, A.; Teets, T. S. Chem. Rev. 2016, 116, 8873-8911. 853 (16) (a) Ekomié, A.; Lefêvre, G.; Fensterbank, L.; Lacôte, E.; 854 Malacria, M.; Ollivier, C.; Jutand, A. Angew. Chem., Int. Ed. 2012, 51, 855 6942-6946. (b) Kyne, S. H.; Lévêque, C.; Zheng, S.; Fensterbank, L.; 856 Jutand, A.; Ollivier, C. Tetrahedron 2016, 72, 7727-7737. 857

(17) Aresta, M.; Giannoccaro, P.; Rossi, M.; Sacco, A. Inorg. Chim. 858 Acta 1971, 5, 115-118.

(18) Wulfsberg, G. In Inorganic Chemistry; University Science Books: 860 Mill Valley, CA, 2000; pp 369-372. 
862 (19) (a) Hathaway, B. J.; Holah, D. G. J. Chem. Soc. 1964, 0, 2408863 2416. (b) Gao, Y.; Guery, J.; Jacoboni, C. Acta Crystallogr., Sect. C: 864 Cryst. Struct. Commun. 1993, 49, 147-151. (c) Zhang, J.; Ensling, J.; 865 Ksenofontov, V.; Gütlich, P.; Epstein, A. J.; Miller, J. S. Angew. Chem., 866 Int. Ed. 1998, 37, 657-660. (d) Buschmann, W. E.; Miller, J. S. Chem. 867 Eur. J. 1998, 4, 1731-1737.

868 (20) Pokhodnya, K. I.; Bonner, M.; DiPasquale, A. G.; Rheingold, A. 869 L.; Her, J.-H.; Stephens, P. W.; Park, J.-W.; Kennon, B. S.; Arif, A. M.; 870 Miller, J. S. Inorg. Chem. 2007, 46, 2471-2477.

871 (21) Voloshin, Y. Z.; Varzatskii, O. A.; Kron, T. E.; Belsky, V. K.; 872 Zavodnik, V. E.; Strizhakova, N. G.; Palchik, A. V. Inorg. Chem. 2000, 873 39, 1907-1918.

874 (22) Birchall, T.; Morris, M. F. Can. J. Chem. 1972, 50, 201-210.

875 (23) Gomez-Romero, P.; Witten, E. H.; Reiff, W. M.; Jameson, G. B. 876 Inorg. Chem. 1990, 29, 5211-5217.

877 (24) Burger, K.; Horvàth, I. Inorg. Chim. Acta 1992, 196, 49-56.

878 (25) Burbridge, C. D.; Goodgame, D. M. L. J. Chem. Soc. A 1968, 0, 879 1410-1413.

880 (26) (a) Bancroft, G. M.; Mays, M. J.; Prater, B. E. Chem. Phys. Lett. 881 1969, 4, 248-250. (b) Itazaki, M.; Ito, M.; Nakashima, S.; Nakazawa, 882 H. Dalton Trans. 2016, 45, 1327-1330.

883 (27) Pokhodnya, K. I.; Bonner, M.; DiPasquale, A. G.; Rheingold, A. 884 L.; Miller, J. S. Chem. - Eur. J. 2008, 14, 714-720.

885 (28) Schmid, R.; Kirchner, K.; Dickert, F. L. Inorg. Chem. 1988, 27, 886 1530-1536.

887 (29) Glavee, G. N.; Klabunde, K. J.; Sorensen, C. M.; Hadjipanayis, 888 G. C. Inorg. Chem. 1995, 34, 28-35.

889 (30) (a) Schaeffer, G. W.; Roscoe, J. S.; Stewart, A. C. J. Am. Chem. 890 Soc. 1956, 78, 729-733. (b) Monnier, G. Ann. Chim. (Paris) 1957, 2, 89114.

892 (31) (a) For a review on the different possible coordination modes 893 of borohydride anion with transition and f-block metals, see: Marks, T. 894 J.; Kolb, J. R. Chem. Rev. 1977, 77, 263-293. (b) Baker, M. V.; Field, 895 L. D. Appl. Organomet. Chem. 1990, 4, 543-549. (c) Langer, R.; Iron, 896 M. A.; Konstantinovski, L.; Diskin-Posner, Y.; Leitus, G.; Ben-David, 897 Y.; Milstein, D. Chem. - Eur. J. 2012, 18, 7196-7209. (d) Koehne, I.; 898 Schmeier, T. J.; Bielinski, E. A.; Pan, C. J.; Lagaditis, P. O.; 899 Bernskoetter, W. J.; Takase, M. K.; Würtele, C.; Hazari, N.; 900 Schneider, S. Inorg. Chem. 2014, 53, 2133-2143.

901 (32) Alberico, E.; Sponholz, P.; Cordes, C.; Nielsen, M.; Drexler, H.902 J.; Baumann, W.; Junge, H.; Beller, M. Angew. Chem., Int. Ed. 2013, 52, 903 14162-14166.

904 (33) Kuhn, N.; Kotowski, H.; Maichle-Mößmer, C.; Abram, U. Z. 905 Anorg. Allg. Chem. 1998, 624, 1653-1656.

906 (34) The weak coordination of the borohydride anion to the metal 907 leads under these conditions leads to the observation of the $[\mathrm{M}-$ $\left.908 \mathrm{BH}_{4}\right]^{+}$fragment. For an example, see ref $31 \mathrm{a}$.

909 (35) Other structures such as $\left[\left(\eta^{1}-\mathrm{H}_{3} \mathrm{BH}\right) \mathrm{Fe}\left(\mathrm{NCCH}_{3}\right)_{5}\right]^{+}$also led to 910 computed nuclear parameters comparable with the experimental data; 911 however, these species were found to be much less stable than the 912 complexes given in Scheme 8 and Table 3 (see the Supporting 913 Information).

914 (36) For a discussion about the potential gap that allows a single 915 electron transfer see: Enemærke, R. J.; Christensen, T. B.; Jensen, H.; 916 Daasbjerg, K. J. Chem. Soc. Perkin Trans. 2 2001, 1620-1630.

917 (37) (a) Abeywickrema, A. N.; Beckwith, A. L. J. Tetrahedron Lett. 918 1986, 27, 109-112. (b) Kropp, M.; Schuster, G. B. Tetrahedron Lett. 919 1987, 28, 5295-5298. (c) Liu, Q.; Han, B.; Zhang, W.; Yang, L.; Liu, 920 Z.-L.; Yu, W. Synlett 2005, 2248-2250. (d) Kobayashi, S.; Kawamoto, 921 T.; Uehara, S.; Fukuyama, T.; Ryu, I. Org. Lett. 2010, 12, 1548-1551. 922 (e) For a recent review on borohydride-mediated radical reactions, 923 see: Kawamoto, T.; Ryu, I. Org. Biomol. Chem. 2014, 12, 9733-9742. 924 (38) Lee, J.-G.; Jung, G.-S.; Lee, S. W. Bull. Korean Chem. Soc. 1998, 925 19, 267-369.

926 (39) Pokhodnya, K. I.; Bonner, M.; DiPasquale, A. G.; Rheingold, A. 927 L.; Her, J.-H.; Stephens, P. W.; Park, J.-W.; Kennon, B. S.; Arif, A. M.; 928 Miller, J. S. Inorg. Chem. 2007, 46, 2471-2477.

929 (40) Gouré, E.; Thiabaud, G.; Carboni, M.; Gon, N.; Dubourdeaux, 930 P.; Garcia-Serres, R.; Clémancey, M.; Oddou, J.-L.; Robin, A. Y.;
Jacquamet, L.; Dubois, L.; Blondin, G.; Latour, J.-M. Inorg. Chem. 931 2011, 50, 6408-6410.

(41) Neese, F. The ORCA program system. Comput. Mol. Sci. 2012, 933 2, 73-78.

(42) Pàpai, M.; Vankò, G. J. Chem. Theory Comput. 2013, 9, 5004- 935 5020.

(43) (a) Becke, A. D. Phys. Rev. A: At., Mol., Opt. Phys. 1988, 38, 937 3098-3100. (b) Perdew, J. P. Phys. Rev. B: Condens. Matter Mater. 938 Phys. 1986, 33, 8822-8824.

(44) Schafer, A.; Huber, C.; Ahlrichs, R. J. J. Chem. Phys. 1994, 100, 940 $5829-5835$

(45) (a) Neese, F. Inorg. Chim. Acta 2002, 337, 181-192. 942 (b) Sinnecker, S.; Slep, L. D.; Bill, E.; Neese, F. Inorg. Chem. 2005, 943 $44,2245-2254$. 